\title{
Flaxseed oil: Extraction, Health benefits and products
}

\author{
Zhen-Xing Tang ${ }^{1 *}$, Rui-Feng Ying ${ }^{2}$, Bin-Feng $\mathrm{Lv}^{3}$, Lan-Hua Yang ${ }^{4}$, Zheng $\mathrm{Xu}^{1}$, Li-Qiang $\mathrm{Yan}^{1}$, Jun-Zhi Bu${ }^{1}$, \\ Yi-Sheng $\mathrm{Wei}^{5}$ \\ ${ }^{1}$ College of Culinary Art, Tourism College of Zhejiang, Hangzhou, Zhejiang, China; ${ }^{2}$ College of Light Industry Science and \\ Engineering, Nanjing Forestry University, Nanjing, Jiangsu, China; ${ }^{3}$ Zhejiang Tianlu Environmental Technology Co. Ltd, \\ Quzhou, Zhejiang, China; ${ }^{4} Y i w u$ Customs, Yiwu, Zhejiang, China; ${ }^{5}$ Chunan Tianlong Biotechnology Co. Ltd, Hangzhou, \\ Zhejiang, China
}

Author for correspondence: Zhen-Xing Tang, Ph.D., College of Culinary Art, Tourism College of Zhejiang, Hangzhou, Zhejiang, China Email: tangzhenxing@126.com

Received: 3 July 2020; Accepted after revision: 12 October 2020; Published: 2 January 2021

(c) 2021 Codon Publications

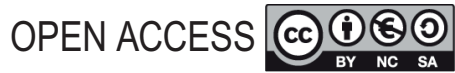

REVIEW ARTICLE

\begin{abstract}
Flaxseed is rich in $\alpha$-linolenic acid (ALA), lignans, proteins and dietary fibers, which has been considered as an important food ingredient. As one of most functional ingredients in flaxseed, flaxseed oil could provide many potential health benefits, such as cardiovascular protection, anti-tumor, anti-inflammatory, live protection, diabetes treatment, etc. Besides mechanical pressing and solvent extraction for flaxseed oil, various new extraction processes, for example, microwave-assisted extraction, supercritical $\mathrm{CO}_{2}$ extraction, subcritical extraction, threephase partitioning, enzyme-assisted three-phase partitioning, etc., have been investigated. Currently, flaxseed oil has been incorporated into some regular food formulations including liquid or solid powder drink, meat products, baking foods, etc. However, due to high ALA in flaxseed oil, it is a great challenge for the development of flaxseed-oil based products. In present paper, the latest development of the extraction of flaxseed oil, the potential benefits of flaxseed oil, and flaxseed oil-based foods, were reviewed. Regarding the studies of flaxseed oil in our group was also highlighted.
\end{abstract}

Keywords: ALA; extraction; flaxseed; foods; health benefits

\section{Introduction}

Flaxseed (Linseed), is one of the oldest oilcrops, is grown in more than 50 countries. The meaning of flaxseed in Latin is "very useful". At present, the main flaxseed grown areas are distributed in the northern hemisphere, including Canada, mainland of China, the America, India, and Ethiopia. Among these countries, Canada and mainland of China are the largest exporters, which account for more than $30 \%$ of flaxseed trades (FAO, 2020).

Flaxseed contains many bioactive compounds including ALA, lignan, protein, mucilage, minerals, phenolic compounds, etc. (Bechlin et al., 2019; Giarola et al., 2019; Lan et al., 2020), which can provide the potential benefits to our body, such as reducing the probability of occurrence of heart diseases and osteoporosis, anti-mammary or prostate gland tumor activities, laxative activity, antiinflammatory activity, and alleviating menopausal symptoms, etc (Afzal et al., 2020; DeLuca et al., 2018; Parikh et al., 2019; Soltanian and Janhorbani, 2018).

The amounts of these components in flaxseed highly depend on many factors such as flaxseed cultivars, harvest time, growth environment, processing, analysis methods, etc (Bekhit et al., 2018; Liu et al., 2018; Marambe and Wanadsundara, 2017). Flaxseed is one of the richest sources of phytoestrogens. In flaxseed, phytoestrogens are existing in the type of lignans (Kajla et al., 2015). The major kind of lignans in flaxseed is 
secoisolariciresinol diglucoside (SDG). The amount of SDG contained in flaxseed varies from 294 to 700 $\mathrm{mg} / 100 \mathrm{~g}$ whole flaxseed (Edel et al., 2015; Goyal et al., 2018). In the study of Gerstenmeryer et al. (2013), 1099 mg SDG/100 g flaxseed was observed. Flaxseed contains around $18-23 \%$ protein which is rich in amino acids including aspartic acid, arginine, cysteine, methionine, etc (Arntfield, 2018; Kaur et al., 2017). Flaxseed protein shows comparable nutritive values and amino acid profiles to soya protein (Bekhit et al., 2018). Flaxseed is also one of excellent sources for phenolic substances. Main types of phenolic substances in flaxseed include phenolic acid compounds, lignans and flavonoid compounds (Kajla et al., 2015). Phenolic acid compounds, for example, ferulic acid, gallic acid, chlorogenic acid, hydroxycinnamic acid, glucosides, p-coumaric acid glucosides, etc., are detected in defatted flaxseed (Deng et al., 2017; Wang et al., 2017). Flaxseed contains many kinds of minerals (Kaur et al., 2017; Oliveira et al., 2017). Magnesium (3575 mg/kg), phosphorous $(5269.20 \mathrm{mg} / \mathrm{kg}$ ) and calcium $(2020.63 \mathrm{mg} / \mathrm{kg}), \mathrm{Fe}(27.89 \mathrm{mg} / \mathrm{kg}), \mathrm{Cu}(5.82 \mathrm{mg} /$ $\mathrm{kg})$, Zn (18.39 mg/kg), were reported (Tuncel et al., 2017). One of anti-nutritional compositions in flaxseed is cyanogenic glycosides, such as linamarin, linustatin, lotasutralin, neolinustatin, etc (Zhao et al., 2019). The content of cyanogenic glycosides in flaxseed significantly depends on flaxseed cultivars, growth areas, processing, etc (Kajla et al., 2015). Yu et al. (2018) reported that the content of cyanogenic glucosides in the investigated flaxseed was ranged between 5.57 and $11.34 \mathrm{mg} \mathrm{HCN} / 100 \mathrm{~g}$. Cyanogenic glycosides can release hydrogen cyanide $(\mathrm{HCN})$ in the intestinal, and thus pose a potential health risk (Bekhit et al., 2018; Kajla et al., 2015). The presence of cyanogenic glycosides in flaxseed limits the development of flaxseed products. Therefore, the reduction of cyanogenic glycosides is highly necessary prior to the application of flaxseed in food industry. Many methods, such as enzymatic method, germination, boiling treatment, mechanical treatment, solvent method, etc., have been investigated (Bekhit et al., 2018; Li et al., 2019).

Generally, the content of flaxseed oil in flaxseed varies from 30 to $44 \%$, which depends on various factors such as location, cultivars, environmental conditions, analysis methods, etc (Kaur et al., 2017; Tuncel et al., 2017). Zou et al. (2017) reported that the crude flaxseed oil contents in 13 flaxseed samples cultivated in China were ranged from 28.9 to $41.4 \%$. Flaxseed is one of the most abundant ALA sources (Abbasi et al., 2019; Lan et al., 2020; Li et al., 2020). The level of ALA in flaxseed oil is between 48 and 62\% (Bakowska-Barczak et al., 2020; Goyal et al., 2018; Moghadam et al., 2019). The content of ALA in flaxseed oil also is affected by environmental conditions, growing conditions and cultivars (Dunford, 2015; Wang et al., 2017). Zou et al. (2017) found the levels of ALA in investigated flasxseed cultivars were ranged from
45.5 to $55.8 \%$. ALA in flaxseed oil from flaxseed cultivars Zhongya1 (55.8\%) and Zhongya4 (53.4\%) showed a higher contents compared to that of the rest investigated flaxseed cultivars.

ALA is considered an essential fatty acid. Many laboratory and epidemiologic studies indicate that ALA from flaxseed oil can reduce occurred rates of heart disease, cancer, arthritis, inflammatory diseases, etc (Kheira et al., 2019; Mosavat et al., 2018; Zhu et al., 2020). 1.1 and 1.6 $\mathrm{g} /$ day ALA recommended intakes for women and men, respectively, have been suggested (Goyal et al., 2018). For lactating and pregnant women, ALA recommended intakes are improved to 1.3 and $1.4 \mathrm{~g} /$ day, respectively. Generally, the recommended dietary intake for flaxseed (about $9.0 \mathrm{~g} /$ per day) is suggested. The reasonable fatty acids balance for $n-6 / n-3$ fatty acids is very important for our health. Many organizations suggest that a ratio of n-6/n-3 fatty acids is from 5:1 to 10:1 (Kumar et al., 2017b). However, a ratio of $n-6 / n-3$ fatty acids in some western countries or Chinese daily diet is far above 10:1. Thus, we need to increase flaxseed oil intake in our daily diet.

The residue from flaxseed pressing is usually regarded as "flaxseed meal", which is rich in proteins, dietary fibers, lignans, orbitides, minerals, cyanogenic glycosides, etc. (Bekhit et al., 2018). Therefore, flaxseed meal shows a great potential to be used as one of functional ingredients in food products. However, it is normally used as one of animal feed ingredients (Aziza et al., 2013). Partially defatted flaxseed meal has been investigated as one of bakery ingredients (Shim et al., 2015; Turner et al., 2014).

Recently, flaxseed oil used as a dietary supplement has gained more consumer interests due to high level of ALA in flaxseed oil. Various flaxseed oil-based products as the form of nutraceuticals or normal foods, like flaxseed blending oils, flaxseed oil yogurt, and flaxseed oil solid drinks etc (Figure 1), are available on the market (Baba et al., 2018; Bolger et al., 2018; Gowda et al., 2018; Manshadi et al., 2019; Tang et al., 2016a, 2016b, 2016c, 2016c, 2016d, 2017, 2018a, 2018b, 2018c, 2018d, 2018e, 2019a, 2019b). Therefore, in this paper, we tried to present the comprehensive development of extraction and health promoting benefits of flaxseed oil, particularly in the last 5 years $(2016-2020)$.

\section{Flaxseed Oil Composition}

Like other edible oils, the main component of flaxseed oil is fatty acid. Other compounds in flaxseed oil, such as volatile compounds, phenolic compounds, tocopherol, phytosterols etc., have been detected. Flaxseed oil contains around 96\% triacylglycerides (TAG) and 1.4\% 
(A)

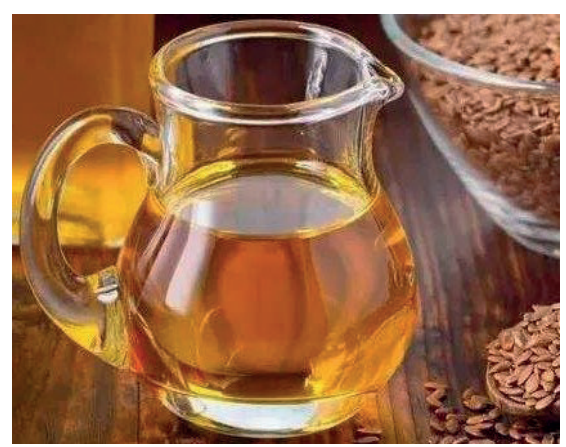

(C)

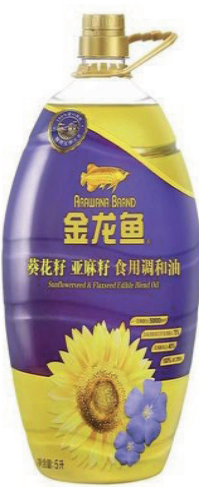

(D)

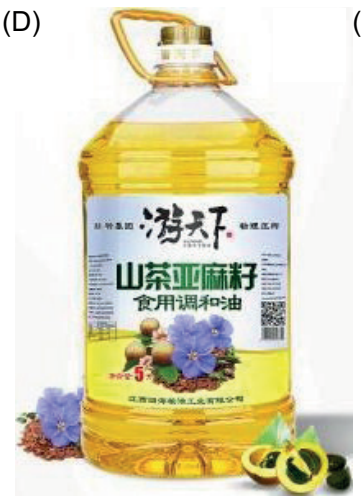

(B)

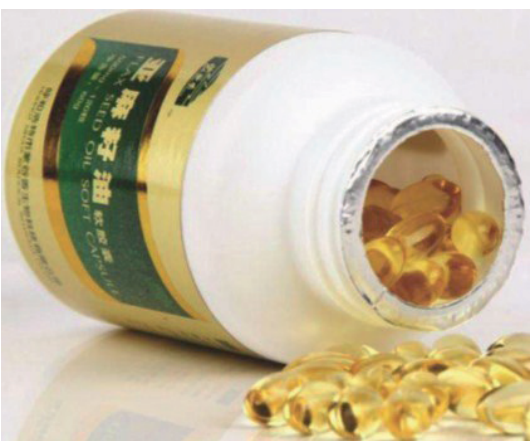

$(\mathrm{E})$

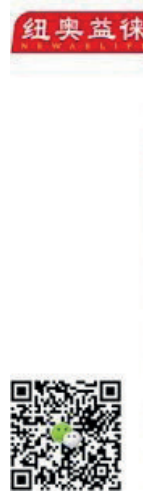

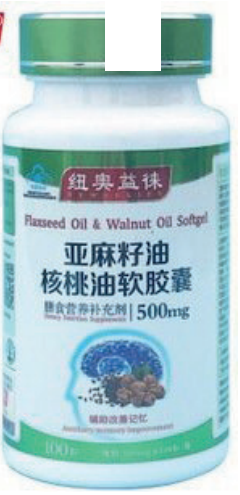

$(\mathrm{F})$

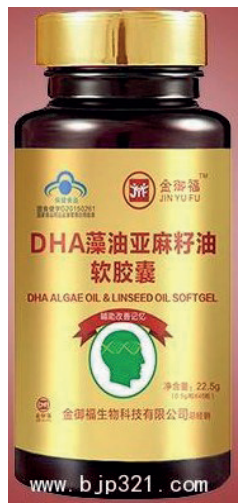

(G)

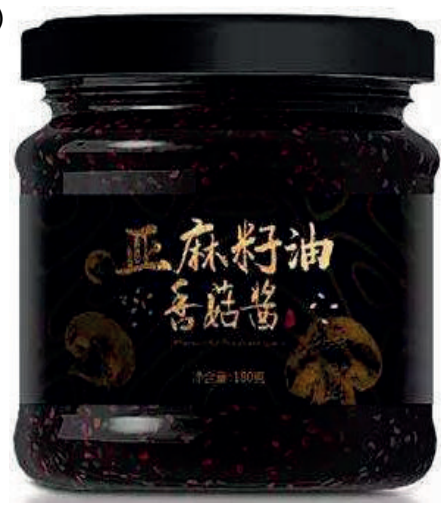

( $\mathrm{H})$

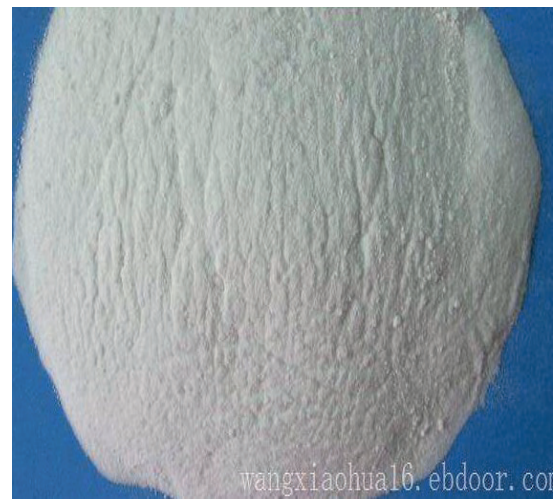

Figure 1. Various flaxseed oil-based commercial products. (A) Flaxseed oil; (B) Flaxseed oil capsule; (C) Blending oils of flaxseed oil and sunflower seed oil; (D) Blending oils of flaxseed oil and camellia oil; (E): Blending oils capsules of flaxseed oil and walnut oil; (F) Blending oils capsules of flaxseed oil and DHA alga oil; (G) Flaxseed oil sauce; (H) Encapsulated flaxseed oil powder.

polar lipids, glyco, and phospholipids (Dunford, 2015). Fatty acids contained in flaxseed oil are given in Table 1. The main TAG in flaxseed oil is trilinolenate (35\%) (Hall et al., 2006). Zhang et al. (2017b) found that fatty acids of flaxseed oils were mainly composed of linolenic acid (53.36-65.84\%), linoleic acid (10.14-16.39\%), oleic acid (10.03-12.37\%), stearic acid (3.98-9.85\%) and palmitic acid (2.41-7.97\%), respectively.

The levels and compositions of volatile compounds in flaxseed oil are one of quality evaluation factors (Wei et al., 2018a, 2018b; Yu et al., 2019c). Yu et al. (2019c) reported that a total number of characteristic aroma compounds from hot-pressed flaxseed and cold-pressed flaxseed oil was 16 and 14, respectively. The unique aroma components in hot-pressed flaxseed oil such as 2, 5-dimethylpyrazine, 2, 3, 5-trimethylpyrazine and (E)-2hexenoaldehyde may be contributed to the roasted and greasy aroma of flaxseed oil. Acetic acid was the unique aroma component in cold pressed flaxseed oil. Wei et al. (2018b) found 57 volatile compounds in flaxseed oil, and constructed aromatic fingerprint of flaxseed oil.

Flaxseed oil also contains many kinds of phenolic compounds, for example, syringic acid, ferulic acid, cinnamic acid, gallic acid, etc. Deng et al. (2017) found the 
Table 1. Fatty acid profiles of whole flaxseed and flaxseed oil.

\begin{tabular}{|c|c|c|c|c|c|}
\hline \multirow{2}{*}{$\begin{array}{l}\text { Fatty acids } \\
\text { Palmitic acid }\end{array}$} & \multicolumn{3}{|c|}{ Whole flaxseed (\%) } & \multicolumn{2}{|c|}{ Flaxseed oil (\%) } \\
\hline & $5.96-7.18^{a}$ & $5.76-6.63^{b}$ & $5.67-6.34^{c}$ & $5.13^{d}$ & $4.66^{\mathrm{e}}$ \\
\hline Stearic acid & $4.38-5.33^{a}$ & $4.13-5.63^{b}$ & $4.28-6.35^{c}$ & $3.38^{d}$ & $4.43^{\mathrm{e}}$ \\
\hline Oleic acid & $18.51-31.19^{a}$ & $26.38-31.38^{b}$ & $22.41-31.13^{c}$ & $19.3^{d}$ & $18.5^{\mathrm{e}}$ \\
\hline Linoleic acid & $12.03-16.52^{\mathrm{a}}$ & $13.85-14.91^{b}$ & $12.45-15.37^{c}$ & $14.0^{\mathrm{d}}$ & $14.5^{\mathrm{e}}$ \\
\hline Linolenic acid & $42.67-58.51^{\mathrm{a}}$ & $43.54-48.35^{b}$ & $45.09-51.09^{c}$ & $55.4^{\mathrm{d}}$ & $55.8^{\mathrm{e}}$ \\
\hline
\end{tabular}

total phenolic compounds were ranged from 109.93 to $246.88 \mathrm{mg}$ GAE/100 g. The phenolic levels in flaxseed oils from varieties Neiya 6, Ningya 17 and Yiya 4 were the lowest, while the highest levels were presented in Longya 9, Jinya 10, Baya 12 and Baya 11. Zhou et al. (2018) showed that the highest level of phenolic compounds in flaxseed oil from Canada was around 38.06 $\mathrm{mg} \mathrm{GAE} / \mathrm{kg}$.

Total tocopherol and $\gamma$-tocopherol contents in flaxseed oil are highly related to oil content (Zou et al., 2017). Zanqui et al. (2015) found that $\beta$-tocopherol was the only observed tocopherol, the content of which was ranged from 25.28 to $33.84 \mathrm{mg} / 100 \mathrm{~g}$ oil. Zhou et al. (2018) reported the total tocopherol content in flaxseed oil sample from Canada could reach up to 536.62 $\mathrm{mg} / \mathrm{kg}$. Recently, Tavarini et al. (2019) reported that flaxseed varieties did not significantly affect the levels of total tocopherols and specific vitamers. In investigated flaxseed varieties, the main form of tocopherols was $\alpha$-tocotrienol. However, in the report of Tuncel et al. (2017), the dominant form of tocopherols was $\gamma$-tocopherol, which were in the range of 146.57$193.14 \mathrm{mg} / 100 \mathrm{~g}$ oil.

Deng et al. (2017) found that the amounts of phytosterols in 32 flaxseed varieties were varied from 56.52 to 125.12 $\mathrm{mg} / \mathrm{g}$. Zhou et al. (2018) indicated that flaxseed oil sample from Canada had the highest content of phytosterol, which was $3671.16 \mathrm{mg} / \mathrm{kg}$.

Unsaponifiable lipid constituents in flaxseed oil generally are hydrocarbons, terpene alcohols, sterols, tocopherols and other phenolic compounds. El-Beltagi et al. (2011) showed that unsaponifiable matter content was not significantly different between investigated flaxseed cultivars. The mean of total hydrocarbons in flaxseed was $86.05 \%$ while the mean of total sterols was $13.95 \% . \mathrm{C}_{26}$ and $\mathrm{C}_{28}$ hydrocarbons were main components in all flaxseed cultivars.

\section{Extraction of Flaxseed Oil}

At present, the most common methods to extract flaxseed oil are mechanical pressing and solvent extraction (Sharma et al., 2019; Shim et al., 2015). Fresh unrefined oil from pressing flaxseed has a nutty flavor and the colour varying from yellow to orange. As other edible oils on the market, it needs to be purified through the process of settling, alkali refining, degumming, bleaching, winterization and deodorization. Sometimes, home-made cold pressed oils can be consumed for cooking directly without further refining processing (Shim et al., 2015). Flaxseed oil extraction can be affected by several factors such as pretreatment of flaxseed, moisture content of flaxseed, cultivars, pressing conditions, etc (Dunford, 2015).

\section{The dehulling process for flaxseed}

The dehulling of oilseeds can improve oil extraction yields and quality. Main substances in flaxseed hull are the mucilage and crude fiber (Kaushik et al., 2016). Several dehulling process for flaxseed such as dry mechanical process, wet process (assisted by mechanical means) and sprouting process have been developed (Lan et al., 2020; Lv and Huang, 2015). Traditionally, the mucilage is removed by wet process aided with mechanical stirring. High extraction temperature can improve the yield of the mucilage in contrast with cold water extraction (Kajla et al., 2015). However, the wet extraction process is not a good choice for removing the hull of flaxseed because it has too many operation sequences (Sharma et al., 2019; Piva et al., 2017). Therefore, other dehulling methods need to be developed.

Dry dehulling process has been proposed since 1939, but only significant progress has been made recently. Particularly in China, it has been applied in industry since 2017. Factors such as moisture content in the 
seed, the pretreatment for the seed, dehulling time, etc., can significantly affect dehulling efficiency (Shim et al., 2015). Recently, Zhang et al. (2020) employed acidic moisture-conditioning plus low temperature drying as a pretreatment for flaxseed before the extraction of flaxseed oil was carried out. The results indicated flaxseed oil recovery rate $83.27 \%$ was obtained under the pretreatment with $0.30 \mathrm{M}$ citric acid and drying at $70^{\circ} \mathrm{C}$ for $1 \mathrm{~h}$. Zheng et al. (2005) found that the reduction of moisture content would result in a significant improvement of the temperatures of flaxseed oil and meals. When moisture content was above $7.5 \%$, the temperature of expressed oil was $49-50^{\circ} \mathrm{C}$, whereas when moisture content was reduced to $6.1 \%$, the expressed oil temperatures could reach to $67^{\circ} \mathrm{C}$. The opposite relationship between flaxseed moisture content and oil yield was found. Singh et al. (2011) found that oil yield significantly increased from 44.4 to $81 \%$ when moisture content in flaxseed decreased from 13.8 to $6.5 \%$.

\section{Mechanical pressing for extracting flaxseed oil}

Due to the high levels of ALA in flaxseed oil, it is necessary to avoid the high temperature during pressing. Generally, flaxseed oil obtained through cold pressing has high levels of ALA (Kulkarni et al., 2017). Several types of flaxseed oil press have been developed, which are ranged from the simple hydraulic press to the more sophisticated continuous screw press (Bekhit et al., 2018). However, cold pressing can also bring negative impacts on the quality of oil. Due to low pressing temperature, microorganisms may not be killed completely during the pressing, which can decrease the quality of flaxseed oil (Shim et al., 2015). Additionally, due to low mass transfer under cold pressing, the contents of vitamins, phospholipids, phytosterols and antioxidants in oil are lower. These compounds are contributed to the stability of flaxseed oil. So, to prolong the shelf life of flaxseed oil, it is highly suggested that flaxseed oil should be kept in a container with dark color, and incorporated with the antioxidants (Tanska et al., 2018).

To overcome the drawbacks of cold pressing, the ways such as flaxseed pressed under more aggressive conditions, heating or enzyme treatments for flaxseed prior to pressing, have been adopted (Dunford, 2015). Kasote et al. (2013) utilized a single screw expeller to extract flaxseed oil. The results showed that the oil yield was improved with the increase of the number of consecutive pressing steps. Compared to the oils from three consecutive pressing steps, the oils with the highest ALA levels were obtained by double pressing. Anwar et al. (2013) showed that the oil yield for enzyme-assisted cold pressing flaxseed was higher than that for without-enzyme treated flaxseed. The extraction methods did not affect most of investigated physicochemical properties of flaxseed oils. Furthermore, the oil from enzyme-treated flaxseed showed better oxidative stability compared to that from without-enzyme treated flaxseed. The authors suggested that enzyme-assisted cold pressing was a good choice for extracting flaxseed oil with high yield and quality.

\section{New extraction methods for flaxseed oil}

Although the mechanical pressing method is quite popular for flaxseed oil processing, a drawback of this technique is the low extraction recovery of the oil. To improve the yield of extracted oil, many new extraction methods, for example, ultrasound-assisted extraction, microwaveassisted extraction, supercritical $\mathrm{CO}_{2}$ extraction, subcritical extraction, three-phase partitioning, enzyme-assisted three-phase partitioning etc., have been developed (Kulkarni et al., 2017; Ren et al., 2015; Rombaut et al., 2017; Piva et al., 2018; Sharma et al., 2019; Suri et al., 2020; Szydlowska-Czerniak et al., 2020; Tan et al., 2016).

Three-phase partitioning process has been developed to extract flaxseed oil, which is usually performed through adding salt and $t$-butanol to aqueous extracts (Kulkarni et al., 2017; Sharma et al., 2019). Tan et al. (2016) utilized enzyme-assisted three-phase partitioning method to extract flaxseed oil, and showed that the yield of flaxseed oil could reach up to $71.68 \%$ under the optimized conditions. Kulkarni et al. (2017) reported that flaxseed oil extraction yield from three-phase partitioning, ultrasonic-pretreated three-phase partitioning, enzyme-pretreated three-phase partitioning was 22.46, 27.05 and $26.24 \%$, respectively. Amongst the methods investigated, the combination enzyme-pretreated and three-phase partitioning may be the most suitable method to extract flaxseed oil.

Supercritical carbon dioxide $\left(\mathrm{SC}-\mathrm{CO}_{2}\right)$ is very suitable for the extraction of heat sensitive and fat-soluble compounds (Dabrowski et al., 2019; Sharma et al., 2019). Kulkarni et al. (2017) reported oil yield from $\mathrm{SC}^{-\mathrm{CO}_{2}}$ was $30.03 \%$. The best quality of flaxseed oil was obtained from $\mathrm{SC}-\mathrm{CO}_{2}$. Dabrowski et al. (2019) investigated the effect of selected parameters in $\mathrm{SC}-\mathrm{CO}_{2}$ such as flow rate $(6-12 \mathrm{~mL} / \mathrm{min})$, temperature $\left(40-80{ }^{\circ} \mathrm{C}\right)$ and extraction time (2-6 h) on the recovery of flaxseed oil. The authors reported the recovery of flaxseed oil was highly associated with extraction parameters, and changed from 28.7 to $92.3 \%$.

Subcritical fluid extraction has been employed to extraction flaxseed oil due to its advantages of used solvent. A good yield of flaxseed oil can be obtained when subcritical propane process is used. Flaxseed oil obtained 
from subcritical propane presented low acidity, showing a better quality compared to flaxseed oil from mechanical extraction (Piva et al., 2018). Piva et al. (2017) employed three methods to extract flaxseed oil, and showed that subcritical propane extraction had a higher yield (28.39\%) compared to other methods.

To improve extraction efficiency, accelerated solvent extraction (ASE) has been employed to extract flaxseed oil. ASE uses organic or aqueous solvents at improved temperatures and pressures to extract flaxseed oil. Khattab and Zeitoun (2013) indicated flaxseed oil yield from ASE (41.9\%), was similar to that from conventional solvent extraction (42.4\%), and higher than that from supercritical $\mathrm{CO}_{2}(36.49 \%)$. The oils obtained from ASE and supercritical $\mathrm{CO}_{2}$ method exhibited similar physicochemical characteristics.

Ultrasonic power as an assistant tool has also been employed to extract flaxseed oil. The main advantages of ultrasonic assisted extraction are less solvent usage and faster extraction process as in contrast with those of the methods without ultrasonic power (Dunford, 2015; Sharma et al., 2019). Zhang et al. (2008) studied the effect of some operating parameters on the recovery of flaxseed oil, and showed that the yield of flaxseed oil increased as ultrasonic power increased, and decreased with the increase of extraction temperature. The flaxseed oil recovery rate could reach $84.9 \%$.

The microwave pre-treatment for flaxseed is an interesting alternative to conventional pressing extraction method. Compared to conventional extraction method, the microwave-assisted extraction shows many advantages, such as shorter processing time, lower solvent usage and higher yield etc (Fathi-Achachlouei et al., 2019). Suri et al. (2020) reported that the treatment of microwave roasting for flaxseeds at $540 \mathrm{~W}$ for $10 \mathrm{~min}$ could improve flaxseed oil yield, oxidative stability and antioxidant activity of flaxseed oils. Szydlowska-Czerniak et al. (2020) optimized the microwave pre-treatment of flaxseed for the extraction of flaxseed oil by response surface methodology. The results showed that microwave treated flaxseed oil presented higher oxidation stability and antioxidant activity compared to those of untreated flaxseed oil. Also, Lv et al. (2020) investigated the effect of microwave pre-treatment for flaxseed on yield and storage stability of flaxseed oil. The results showed that microwave pre-treatment could improve the yield and polyphenol content of flaxseed oil, and it could delay the oxidation rate of flaxseed oil, thereby improving the storage stability of flaxseed oil.

\section{Health Promoting Benefits of Flaxseed Oil}

\section{Flaxseed oil in cardiovascular diseases and atherosclerosis treatment}

Cardiovascular disease (CVD), one of the disorders of heart and blood vessels, is recognized as the leading health threats in worldwide countries (Goyal et al., 2018). Recently, many studies have showed that flaxseed oil has an ability in reducing CVD risk in vitro or in vivo (Table 2).

Hypercholesterolaemia and inflammatory are major risk factors in the development of CVD. Tzang et al. (2009) indicated flaxseed oil presented a hypocholesterolemic ability in contrast with other oils (coconut oil, butter) did. Higher faecal contents of triacylglycerol and cholesterol in flaxseed oil group were observed. Atherosclerosis refers to one kind of the diseases that caused by depositing and accumulating of the lipids in blood cell walls. The formation and development of atherosclerosis are attributed to many factors such as interleukin 1-b, hypercholesterolemia, tumor necrosis factor, eicosanoids cytokines, platelet-activating factor and reactive oxygen

Table 2. Impact of flaxseed oil ingestion on reducing incidence of cardiovascular diseases.

\begin{tabular}{|c|c|c|c|}
\hline Amount ingestion of flaxseed oil & Model system & Results & References \\
\hline $7.0 \%$ flaxseed oil & Hamsters & $\begin{array}{l}\text { Flaxseed oil group showed higher triacylglycerol and cholesterol } \\
\text { in faeces. }\end{array}$ & Tzang et al. (2009) \\
\hline $10 \%$ flaxseed oil & Mice & $\begin{array}{l}\text { Replacement of lard with flaxseed oil significantly improved } \\
\text { atherosclerosis, oxidative stress, and lipid abnormalities. }\end{array}$ & Han et al. (2018) \\
\hline $\begin{array}{l}\text { Flaxseed oil and } \alpha \text {-lipoic acid } \\
(8.0 \mathrm{~g} / \mathrm{kg})\end{array}$ & Rats & $\begin{array}{l}\text { Simultaneous feeding flaxseed oil and } \alpha \text {-lipoic acid could } \\
\text { reduce the levels of LDL-C, TC and plasma TG. }\end{array}$ & Xu et al. (2012) \\
\hline 0-55.6 mg/L flaxseed oil & $\begin{array}{l}\text { Human } \\
\text { umbilical vein } \\
\text { endothelial cell }\end{array}$ & $\begin{array}{l}\text { ALA in flaxseed oil at high concentrations could inhibit } \\
\text { inflammatory responses induced by lipopolysaccharide } \\
\text { in human umbilical vein endothelial cells. }\end{array}$ & Shen et al. (2018) \\
\hline 250 and $500 \mathrm{mg} / \mathrm{kg}$ & Rats & $\begin{array}{l}\text { Dietary flaxseed oil could significantly decrease the arsenic } \\
\text { accumulation, as well as reduce cardiac structural alterations. }\end{array}$ & $\begin{array}{l}\text { Varghese et al. } \\
\text { (2017) }\end{array}$ \\
\hline
\end{tabular}


species. Han et al. (2018) reported that the partial substitution of lard using flaxseed oil significantly relieved atherosclerosis symptoms, improved oxidative stress, and reduced the abnormalities of lipid and inflammation. The authors indicated that dieting flaxseed oil can be considered to be as a dietary therapy in the treatment of atherosclerosis. Shen et al. (2018) showed that ALA in flaxseed oil at high levels could reduce inflammatory responses in lipopolysaccharide-induced human umbilical vein endothelial cells. Varghese et al. (2017) investigated the protective activity of flaxseed oil against the cardiac toxicity induced by $\mathrm{As}_{2} \mathrm{O}_{3}$. The results showed that dietary flaxseed oil could significantly decrease the arsenic accumulation and cardiac structural alterations.

\section{Cancer treatment by flaxseed oil}

At present, many scientists are interested in building the relationship between flaxseed dietary and cancer risk. Many studies demonstrate that flaxseed oil shows the inhibition growth ability of many kinds of cancers, such as colon cancer, mammary tumor, breast cancer, etc., even at a more advanced stage of cancer (Table 3). Buckner et al. (2019) showed that flaxseed oil could decrease various cancer cell lines growth through a dose-dependent manner, and disrupt mitochondrial function of B16-BL6 and MCF-7 cells. In the study of Wiggins et al. (2015), it was also indicated that flaxseed oil could reduce the growth of breast cancer cell lines, and increase the apoptosis by modifying signaling pathways. Flaxseed oil also can improve the effectiveness of anti-cancer drugs to inhibit the growth of some types of cancer cells. Mason et al. (2015) found flaxseed oil could enhance the anti-human breast tumors ability of drug trastuzumab through reducing the growth of HER2-overexpressing tumors. Although many substances in flaxseed showed anti-tumor activity, more studies should be carried out to clarify the mechanisms that which components or how show the ability to reduce cancer development.

\section{Flaxseed oil in kidney diseases}

The kidney plays an important role in excreting metabolites and harmful compounds that enter our body (Omar, 2018). Kidney dysfunctions are one of the serious diseases for our health, specially for older adults. At the late stage of renal disease, special treatments such as the dialysis or organ transplant, are highly needed (Table 3). Omar (2018) evaluated effect of dietary flaxseed oil on renal toxicity induced by thioacetamide in male rats. The results showed that feeding flaxseed oil could protect the changes of biochemical parameters and histopathological structures induced by thioacetamide. The speculated renal protective agent in flaxseed oil was due to the antioxidant compounds in flaxseed oil. Kheira et al. (2019) showed that feeding flaxseed oil could significantly down-regulate the expression levels of interleukin (IL) -6 and IL- $1 \beta$ in kidney compared to the control. The authors indicated that flaxseed oil could ameliorative the renal injury induced by cisplatin due to anti-inflammatory ability of ALA in flaxseed oil.

\section{Flaxseed oil in liver health}

The liver is the largest metabolic organ in our body, which is easily affected by many inflammatory compounds such as viral, bacterial, alcohol, endotoxins, etc. Flaxseed oil presents hepatoprotective activity through the inhibition of inflammatory signaling pathways. Wang et al. (2018) showed flaxseed oil could decrease the expression levels of interleukin-6, tumor necrosis factor $\alpha$, and cycloxygenase. Zhang et al. (2017a) indicated dietary flaxseed oil could reduce the abnormal elevated contents of aspartate

Table 3. Impact of flaxseed oil ingestion on reducing incidence of cancer and kidney diseases.

\begin{tabular}{|c|c|c|c|}
\hline Amount ingestion of flaxseed oil & Model system & Results & References \\
\hline $4.0 \%$ flaxseed oil in the diet & Mice & $\begin{array}{l}\text { The activity of the anti-cancer drug of trastuzumab in reducing } \\
\text { the growth of HER2-overexpressing human breast tumors was } \\
\text { improved further in flaxseed oil group. }\end{array}$ & Mason et al. (2015) \\
\hline 0.30 or $0.90 \%$ flaxseed oil & Cell lines & $\begin{array}{l}\text { Flaxseed oil could induce the apoptosis of B16-BL6 murine } \\
\text { melanoma and MCF-7 breast cancer cells, and thus led to the } \\
\text { disruption of mitochondrial function in B16-BL6 and MCF-7 } \\
\text { cells. }\end{array}$ & $\begin{array}{l}\text { Buckner et al. } \\
\text { (2019) }\end{array}$ \\
\hline $4.0 \%$ flaxseed oil in the diet & Mice & $\begin{array}{l}\text { Flaxseed oil could reduce the growth, and increase apoptosis in } \\
\text { breast cancer cell lines. }\end{array}$ & $\begin{array}{l}\text { Wiggins et al. } \\
\text { (2015) }\end{array}$ \\
\hline $2.0 \mathrm{~g}$ flaxseed oil/kg body weight/day & Mal rats & $\begin{array}{l}\text { Flaxseed oil in the diet showed the protection ability against } \\
\text { the changes of biochemical parameters and histopathological } \\
\text { structures induced by thioacetamide. }\end{array}$ & Omar (2018) \\
\hline $15 \%$ flaxseed oil in the diet & Rats & $\begin{array}{l}\text { Flaxeed oil could ameliorate the impact of cisplatin on the injury } \\
\text { of rat kidney. }\end{array}$ & $\begin{array}{l}\text { Naqshbandi et al. } \\
\text { (2013) }\end{array}$ \\
\hline
\end{tabular}


aminotransferase and alanine aminotransferase in mice. It is suggested that dietary flaxseed oil could ameliorate alcoholic liver disease through its anti-inflammation activity and gut microbiota modulating ability. Also, Wang et al. (2016) demonstrated dietary flaxseed oil decreased the elevation of plasma endotoxin content, and suppressed the inflammation induced by endotoxin.

\section{Flaxseed oil in bone health}

The investigation of effect of flaxseed oil on the health of bone may provide an alternative way to treat osteoporosis. Many studies have showed that ALA in flaxseed oil presents beneficial effects on bone metabolism (Table 4). Chen et al. (2019b) indicated that flaxseed oil could ameliorate bone loss induced by a high fat diet through osteoblastic function in rat primary osteoblasts. El-Saeed et al.
(2018) showed that feeding flaxseed oil could increase the contents of bone minerals. The authors suggested the dietary of flaxseed oil could provide beneficial effect on the treatment of osteoporosis.

\section{Flaxseed oil in diabetes}

Diabetes mellitus refers to one kind of metabolic diseases with the characteristics of high levels of blood glucose. If not being treated appropriately, it can lead to the formation of many complications (Goyal et al., 2018; Lim et al., 2017; Soleimani et al., 2017a, 2017b). Clinical evidence have showed that these complications can be controlled well through many dietary therapies. Many studies have indicated that flaxseed oil plays an important role in the treatment of diabetes (Table 5). It has been shown that feeding flaxseed oil in the diet can show a

Table 4. Impact of flaxseed oil ingestion on the health of liver and bone.

\begin{tabular}{|c|c|c|c|}
\hline Amount ingestion of flaxseed oil & Model system & Results & References \\
\hline $\begin{array}{l}\text { Lieber-DeCarli liquid diets containing } \\
\text { corn oil and flaxseed oil }\end{array}$ & Mice & $\begin{array}{l}\text { Dietary flaxseed oil could reduce the abnormal elevated levels } \\
\text { of aspartate aminotransferase and alanine aminotransferase in } \\
\text { mice with alcoholic liver disease. }\end{array}$ & $\begin{array}{l}\text { Zhang et al. } \\
\text { (2017a) }\end{array}$ \\
\hline $\begin{array}{l}\text { Lieber-DeCarli liquid diets containing } \\
\text { corn oil and flaxseed oil }\end{array}$ & Mice & $\begin{array}{l}\text { Dietary flaxseed oil decreased the elevated content of plasma } \\
\text { endotoxin, as well as, reduced the inflammation responses } \\
\text { induced by endotoxin. }\end{array}$ & $\begin{array}{l}\text { Wang et al. } \\
(2016)\end{array}$ \\
\hline $5.0 \%$ flaxseed oil diet & Piglet & $\begin{array}{l}\text { Flaxseed oil could decrease the expression of interleukin- } 6 \text {, } \\
\text { tumor necrosis factor- } \alpha \text { and cycloxygenase } 2 \text {, and thus led to } \\
\text { the alleviation of liver injury induced by lipopolysaccharide. }\end{array}$ & $\begin{array}{l}\text { Wang et al. } \\
(2018)\end{array}$ \\
\hline $10 \%$ flaxseed oil diet & Rats & $\begin{array}{l}\text { Flaxseed oil could reduce bone loss induced by high-fat-diet } \\
\text { through improving osteoblastic function in rat. }\end{array}$ & Chen et al. (2019) \\
\hline Flaxseed oil in the diet & Rats & $\begin{array}{l}\text { The increase of bone mineral levels was observed in flaxseed } \\
\text { oil group. }\end{array}$ & $\begin{array}{l}\text { El-Saeed et al. } \\
\text { (2018) }\end{array}$ \\
\hline
\end{tabular}

Table 5. Impact of dietary flaxseed oil on reducing the incidences of diabetes.

\begin{tabular}{|c|c|c|c|}
\hline Amount ingestion of flaxseed oil & Model system & Results & References \\
\hline $\begin{array}{l}1000 \mathrm{mg} / \text { day omega-3 from } \\
\text { flaxseed oil }\end{array}$ & Human & $\begin{array}{l}\text { The ingestion of flaxseed oil could significantly reduce the } \\
\text { levels of VLDL-cholesterol and serum triglycerides, and } \\
\text { increase insulin sensitivity check index. }\end{array}$ & $\begin{array}{l}\text { Soleimani et al. } \\
\text { (2017a) }\end{array}$ \\
\hline $\begin{array}{l}1000 \mathrm{mg} \text { faxseed oil supplements } \\
\text { containing } 400 \mathrm{mg} \mathrm{ALA}\end{array}$ & Human & $\begin{array}{l}\text { Flaxseed oil supplementation could improve gene expression } \\
\text { levels of peroxisome proliferator-activated receptor gamma } \\
\text { (PPAR- } \gamma \text { ), tumor necrosis factor alpha (TNF- } \alpha \text { ) and lipoprotein } \\
\text { (a) (LP(a)) }\end{array}$ & $\begin{array}{l}\text { Hashemzadeh et al. } \\
\text { (2017) }\end{array}$ \\
\hline $\begin{array}{l}1000 \mathrm{mg} / \text { day omega- } 3 \text { from flaxseed } \\
\text { oil plus } 400 \mathrm{IU} \text { vitamin } \mathrm{E}\end{array}$ & Human & $\begin{array}{l}\text { Co-supplementation of ALA and vitamin E could significantly } \\
\text { improve total antioxidant capacity, and significantly decrease } \\
\text { the level of formed malodialdehyde. }\end{array}$ & $\begin{array}{l}\text { Jamilian et al. } \\
(2017)\end{array}$ \\
\hline $10 \%$ flaxseed oil in the diet & Rats & $\begin{array}{l}\text { Flaxseed oil in the diet could significantly reduce the levels of } \\
\text { fasting blood glucose, blood lipid, plasma lipopolysaccharide, } \\
\text { glycated hemoglobin, (TNF)- } \alpha \text {, IL-6, IL-17A, interleukin (IL)-1ß. }\end{array}$ & Zhu et al. (2020) \\
\hline $1.2 \mathrm{~mL}$ flaxseed oil/kg/day & Male albino rats & $\begin{array}{l}\text { The ingestion of flaxseed oil could decrease the level of kinase } \\
\mathrm{C} \text { isozymes, and improve the sensitivity of insulin of rats with } \\
\text { diabetes. }\end{array}$ & $\begin{array}{l}\text { Hussein et al. } \\
(2014)\end{array}$ \\
\hline
\end{tabular}


health promoting benefits for diabetics through modulating insulin sensitivity in phospholipids membranes, modulating gut microbiota, or reducing inflammation in the body. Hashemzadeh et al. (2017) found that dieting flaxseed oil could improve the gene expression amounts of peroxisome proliferator activated receptor gamma (PPAR- $\gamma$ ), tumor necrosis factor alpha (TNF- $\alpha$ ), lipoprotein (a) (LP(a)) in type II diabetic patients with coronary heart disease. Soleimani et al. (2017a) showed that flaxseed oil supplementation could significantly reduce the amounts of VLDL-cholesterol and serum triglycerides, and increase insulin sensitivity checking index. Zhu et al. (2020) investigated effect of adding flaxseed oil in the diet on rats with type II diabetes mellitus. The results indicated dieting flaxseed oil could significantly reduce the concentrations of fasting blood glucose, blood lipid, plasma lipopolysaccharide, glycated hemoglobin, TNF- $\alpha$, IL-6, IL-17A, interleukin (IL)-1 $\beta$ and malondialdehyde (MDA), in contrast with the control. Jamilian et al. (2017) studied impact of ALA and vitamin E co-supplementation on biomarkers of oxidative stress and inflammation in women with gestational diabetes. The results showed that ALA and vitamin E co-supplementation could significantly improve total antioxidant ability, and significantly decrease the level of MDA.

\section{Flaxseed oil in arthritis and inflammation}

Arthritis, one kind of joint disorder diseases involved joint pain, is usually caused by inflammatory substances and joint wear (Mosavat et al., 2018). Many studies have showed that flaxseed oil with an anti-inflammation ability, has a potential application in the treatment of arthritis (Table 6). Mosavat et al. (2018) found that flaxseed oil was effective in the treatment of knee oseoarthritis, especially in the aspects of ameliorating the severe symptoms and functional status, because of anti-inflammatory ability of flaxseed oil.

\section{Flaxseed oil in brain health}

Many flaxseed oil-based products are claimed as "health for brain". Some studies have showed that flaxseed oil plays an important role in maintaining nerve function and metabolism activity of brain tissue. Tian et al. (2011) studied the changes of brain tissue in young mice fed polyunsaturated fatty acids with different ratios during maternal pregnancy and lactation. The results indicated dieting flaxseed oil could significantly increase the expression levels of brain neuron-specific enolase, myelin basic protein and glial fibrillary acidic protein. The authors indicated that higher intake amounts of $n-3$ polyunsaturated fatty acids with n- $6 / n-3$ fatty acids at around $1-2: 1$, was more helpful to the development of early brain. In the study of Ismail et al. (2016), flaxseed oil presented neuroprotective activity in rats' brain induced by gamma-irradiation or carbon tetrachloride.

\section{Flaxseed oil in obesity}

Obesity has been popular in many countries, which is highly related to some chronic diseases, for example, type II diabetes, cardiovascular disease, cancer, metabolic syndrome, etc (Moura-Assis et al., 2018; Yu et al., 2017). Akrami et al. (2018) clearly showed that dieting flaxseed oil or sunflower seed oil could significantly reduce the weight of the patients. In addition, feeding flaxseed oil significantly decreased waist circumference of the patients. Yu et al. (2017) reported that feeding medium

Table 6. Impact of flaxseed oil ingestion on rheumatoid arthritis and inflammatory diseases.

\begin{tabular}{|c|c|c|c|}
\hline Amount ingestion of flaxseed oil & Model system & Results & References \\
\hline $\begin{array}{l}\text { Flaxseed oil and fish oil (n-6/n-3 fatty } \\
\text { acid ratio of } 5: 1)\end{array}$ & $\begin{array}{l}\text { Mature female } \\
\text { cats }\end{array}$ & $\begin{array}{l}\text { The dietary of flaxseed oil and fish oil could improve the } \\
\text { level of skin leukotriene LTB5, and reduce the skin leukocyte } \\
\text { proliferative response. }\end{array}$ & Park et al. (2011) \\
\hline $\begin{array}{l}\text { 1-3 } \mathrm{mL} \text { flaxseed oil/kg with regular } \\
\text { diet }\end{array}$ & Albino rats & $\begin{array}{l}\text { The dietary of flaxsee oil could significantly reduce protein } \\
\text { exudation and leucocyte migration levels in peritoneal fluid. }\end{array}$ & $\begin{array}{l}\text { Kaithwas and } \\
\text { Majumdar (2010) }\end{array}$ \\
\hline $2.4 \mathrm{~mL}$ flaxseed oil $/ \mathrm{kg}$ body weight & Female dogs & $\begin{array}{l}\text { The dietary of flaxseed oil could significantly down-regulate } \\
\text { the expression of inflammatory genes, for example HSP90, } \\
\text { IL1 } \beta \text { etc. }\end{array}$ & $\begin{array}{l}\text { Purushothaman } \\
\text { et al. (2014) }\end{array}$ \\
\hline 20 drops every $8 \mathrm{~h}$ & $\begin{array}{l}\text { Men and } \\
\text { women with } \\
\text { ages } 40-70 \\
\text { yeas old }\end{array}$ & $\begin{array}{l}\text { Flaxseed oil was effective in improving clinical parameters of } \\
\text { knee oseoarthritis. }\end{array}$ & $\begin{array}{l}\text { Mosavat et al. } \\
(2018)\end{array}$ \\
\hline $15 \mathrm{~mL}$ flaxseed oil/day & Humans & $\begin{array}{l}\text { The dietary of flaxseed oil did not significantly influence on the } \\
\text { levels of the inflammatory markers, for example adiponectin, } \\
\text { TNF- } \alpha \text {, and C-reactive protein. }\end{array}$ & $\begin{array}{l}\text { Kontogianni et al. } \\
\text { (2013) }\end{array}$ \\
\hline
\end{tabular}


dose of flaxseed oil could effectively inhibit the metabolic activation of adipose tissue macrophages, and thus improved tissue insulin signaling.

\section{Flaxseed oil in ulcerative colitis treatment}

Ulcerative colitis is one kind of chronic inflammatory bowel diseases, which can greatly affect work and daily lives of the patients (Nascimento et al., 2020). Zhou et al. (2020) showed that flaxseed oil could decrease the inflammation in colon, and recovered the microbiota profiles in rats at a certain extent. The authors indicated that flaxseed oil could be used as a beneficial agent for the management of ulcerative colitis possibly through regulating the levels of inflammatory factors and gut microbiota. Morshedzadeh et al. (2019) evaluated impact of flaxseed oil on serum contents of metabolic parameters, inflammatory markers and the severity of disease in the patients with ulcerative colitis. The results showed that the parameters of IL-6, interferon gamma, waist circumference significantly decreased, and the parameter of transforming growth factor beta increased significantly in flaxseed oil group compared to the control.

\section{Flaxseed Oil-Based Products}

Flaxseed has been used as a dietary supplement in our daily life for many years. Whole or milled flaxseeds can be conveniently used as additives in dough, batters, and various baked products. Furthermore, flaxseed flour can be served as wheat flour or egg substitute especially in some baked products such as breads, muffins and cookies etc. As one of the main constituents in flaxseed, flaxseed oil is gaining popularity because of the high level of ALA (Bekhit et al., 2018; Mohseni and Goli, 2019). However, the development of flaxseed oil-based is a challenging work because ALA in flaxseed oil is highly sensitive to external factors, for example, oxygen, light, high temperature, etc (Bekhit et al., 2018; Mohseni and Goli, 2019). If flaxseed oil is in an improper storage, it is easily emerging rancidity, and leads to poor sensory quality. Therefore, flaxseed oil is usually stored in dark bottles. Regarding the applications of flaxseed oil in various foods, many studies have been carried out in laboratory scale. Flaxseed oil has been added into many kinds of baked foods, beverages, meat products and many other foods (Baba et al., 2018; Bolger et al., 2018; Farbod et al., 2015; Gowda et al., 2018; Goyal et al., 2016; Kumar et al., 2017a; Reddy et al., 2016; Ramel et al., 2017; Osuna et al., 2018; Veena et al., 2017). At present, soft capsule of flaxseed oil has also been sold as a functional food supplement in China. Furthermore, some flaxseed oilbased products developed in our group, such as flaxseed instant powder, flaxseed yogurt, flaxseed baked products, have been available on the market.

\section{Flaxseed oil}

Generally, flaxseed is roasted between 105 and $160^{\circ} \mathrm{C}$ for several hours prior to flaxseed pressing (Yang et al., 2011). Yu et al. (2019a) investigated effect of different pretreatment processes such as normal-pressure roasting, microwave and high-pressure roasting, on the properties of obtained flaxseed oil. The results showed that the quality of obtained flaxseed oil pretreated through the combination of microwave and high-pressure roasting, were better compared to those of pressed flaxseed oil pretreated by normal-pressure frying $\left(170^{\circ} \mathrm{C}\right.$, $45 \mathrm{~min}$ ). In addition, obtained flaxseed oil pretreated by high-pressure roasting had a pleasant flavor. In the same group, Yu et al. (2019b) studied the impact of roasting temperature for flaxseed on the quality of obtained flaxseed oil. The results showed that flavor of pressed flaxseed oil changed from nutty aroma to strong burnt taste, and the color became darker, as roasting temperature increased. The roasting temperature could significantly affect the stability of ALA in flaxseed oil. What's more, the contents of $\mathrm{V}_{\mathrm{E}}$, total phenols and polysterols decreased gradually with the increase of roasting temperature.

Many studies have showed that that the content of ALA in flaxseed oil significantly reduces after being treated at high temperature, and results in the reduction of the nutritional values of flaxseed oil. Hall et al. (2006) found the quality of flaxseed oil did not decrease when the temperature was below $177^{\circ} \mathrm{C}$. However, when the cooking temperature was more than $177^{\circ} \mathrm{C}$, ALA content was significantly reduced. Chen et al. (2019a) reported the content of ALA in flaxseed oil decreased significantly at high temperature $\left(250^{\circ} \mathrm{C}\right)$. After flaxseed oil was heated at 200 or $250^{\circ} \mathrm{C}$ for $2 \mathrm{~h}$, ALA content decreased by 6.1 and $57.7 \%$, respectively. The authors suggested heating temperature for flaxseed oil should be controlled under $200^{\circ} \mathrm{C}$, and heating time should not be too long. This information may be good for Chinese cook because stir frying is a very popular cooking method. Even so, we highly recommend flaxseed oil had better be cooked at low temperature $\left(<180^{\circ} \mathrm{C}\right)$.

The levels of antioxidants in the oils can significantly influence the oxidation stability of flaxseed oil (Shadyro et al., 2020). There are some antioxidants such as tocopherols, phenolic acids, flavonoids, etc., in flaxseed oil (Kajla et al., 2015). Heating treatment can destroy these natural antioxidants, thus leads to the reduction of oxidation stability (Kajla et al., 2015; Yu et al., 2019a). To improve the storage stability of flaxseed oil, various antioxidants, for example flaxseed extracts, $\alpha$-tocopherol mixture, etc., have been applied for the protection of flaxseed oil (Mohanan et al., 2018; Shadyro et al., 2020; Sielicka and Malecka, 2017). 


\section{Encapsulation of flaxseed oil}

Due to the poor storage stability of flaxseed oil, encapsulation technology for flaxseed oil has been investigated (Fioramonti et al., 2019; Goyal et al., 2018). Recently, many flaxseed-based products have been developed in our group, some of which are commercialized. The product of flaxseed instant powder based on this technology has been available since 2014 (Lv and Huang, 2015). However, many consumers give us the feedback that protein content in flaxseed instant powder is too low. Therefore, we have updated the formulation of flaxseed instant powder. In new formulation, around 10\% milk protein was added. The new product of flaxseed instant powder enriched with milk protein has been available in 2019. Flaxseed instant powder can be used as a functional additive (Tang et al., 2016, 2017, 2018, 2019). Many normal foods incorporated with flaxseed instant powder such as biscuit, sweet, snack bar, milk tablet, liquid drinks, etc., have been developed.

The co-encapsulation technology refers to encapsulation more than one bioactive components at the same time, which has been widely used as a delivery system (Eratte et al., 2015, 2016, 2018). Co-encapsulation process can low production cost, and improve the product quality. Products containing encapsulated $\omega-3$ oils or probiotics have been available. At present, there are some products composed of the mixture encapsulated $\omega-3$ oils and encapsulated probiotics on the market. Products containing with co-encapsulated $\omega-3$ oils and probiotics are not available so far. Regarding the studies on the co-encapsulation of ALA and probiotics is still limited. Eratte et al. $(2015,2016)$ co-encapsulated $\omega-3$ oil and probiotics using the combination of complex coacervation and by spray drying technology. The results showed that oxidative stability and cell viability were highly improved. Stratulat et al. (2014) co-encapsulated vitamins E, A and $\mathrm{CoQ}_{10}$ in flaxseed oil emulsion stabilized with calcium caseinate, and studied the stability of the encapsulated bioactives in cheese milk. The results indicated that the stability of co-encapsulated bioactives in cheese milk could be remained during the investigated storage periods.

\section{Blending oil}

As is well known, one particular oil can not satisfy all the nutritional requirements (Hashempour-Baltork et al., 2016; Torri et al., 2019). Therefore, in order to satisfy commercial requirements, oils need to be modified. Among modification methods for oils, blending oils may be one of the simplest methods to modify fatty acid profile, physicochemical and nutritional properties which can reach to the requirement of industrial applications (Hashempour-Baltork et al., 2016). Presently, many blending oils with improved stability and nutritional properties have been marketed. In our group, blend oil made from flaxseed oil and grapeseed oil, has been commercialized (unpublished work). Blending flaxseed oil with palm oil was used to prepare fat spreads (El-Waseif et al., 2013, 2014). The results showed that $\omega-3$ content in fat spreads was significantly improved due to the presence of flaxseed oil. As a result, oxidation stability of fat spread samples contained flaxseed oil was lower than the control. Sensory evaluation results indicated that incorporation flaxseed oil into fat spread did not significantly impact the sensory properties. Meinhart et al. (2017) showed the stability of blend oils (soybean, flaxseed and safflower oils: 75: 20: $5 \mathrm{~g} / 100 \mathrm{~g}$ ) was higher compared to that of soybean oil. Additionally, the obtained blend oil with lower n-6/n-3 ratio, had higher nutritional values compared to the pure soybean oil. The authors suggested the blend oils could improve the nutritional quality of frying oil, and enhance the intake of $\omega-3$ in our daily diet. Kumar et al. (2017a) studied the stability of ALA in the blend oils of coconut oil and flaxseed oil (70/30) during deep-fat frying of snack food. The authors found ALA content in obtained snack food was around $27.48 \%$ when it was fried at $140^{\circ} \mathrm{C}$ for $360 \mathrm{~s}$.

\section{In food products}

Foods based on flaxseed oil such as breads, cookies, drinks, ice cream, salad dressings, sausages, egg sticks, yoghurts, fat spreads, surimmi, cheese, etc., have been reported (Manshadi et al., 2019; Ramel and Marangoni, 2017). Various food products incorporated with flaxseed oil are showed in Table 7.

Table 7. Applications of flaxseed oil in foods.

\begin{tabular}{|c|c|c|}
\hline Food types & Additions & References \\
\hline $\begin{array}{l}\text { Alaska pollock } \\
\text { surimi }\end{array}$ & $\begin{array}{l}10 \% \text { oil (flaxseed: algae: } \\
\text { menhaden, 8: } 1: 1 \text { ) }\end{array}$ & $\begin{array}{l}\text { Debusca et al. } \\
\text { (2013) }\end{array}$ \\
\hline Cheese & $1.0 \%$ flaxseed oil & $\begin{array}{l}\text { Aguirre and } \\
\text { Canovas (2012) }\end{array}$ \\
\hline $\begin{array}{l}\text { Shortening \& } \\
\text { cookies }\end{array}$ & $0-50 \%$ flaxseed oil & $\begin{array}{l}\text { Rangrej et al. } \\
\text { (2015) }\end{array}$ \\
\hline Bread & $\begin{array}{l}1.0,2.5,5.0 \text { and } 10 \% \\
\text { flaxseed oil (powder) }\end{array}$ & $\begin{array}{l}\text { Gokmen et al. } \\
\text { (2011) }\end{array}$ \\
\hline Ice cream & $4.0 \%$ flaxseed oil powder & Gowda et al. (2018) \\
\hline Milk & $4.0 \%$ flaxseed oil & $\begin{array}{l}\text { Tang et al. (2016a, } \\
2016 b, 2016 c \text {, } \\
2016 d)\end{array}$ \\
\hline $\begin{array}{l}\text { Solid drink } \\
\text { powder }\end{array}$ & $50 \%$ flaxseed oil & $\begin{array}{l}\text { Tang and Bian } \\
(2018 c, 2018 d)\end{array}$ \\
\hline Yoghurts & $\begin{array}{l}2.0 \% \text { flaxseed oil } \\
2.0 \% \text { flaxseed oil plus } \\
\text { flaxseed flour } 1.0 \%\end{array}$ & $\begin{array}{l}\text { Tang (2019a, } \\
\text { 2019b) } \\
\text { Kumar et al. (2017) }\end{array}$ \\
\hline
\end{tabular}




\section{Bakery products}

Many studies have investigated the potential applications of flaxseed oil in various bakery products (Osuna et al., 2018). Although most of the studies are focused on the laboratory scale, the results indicate bakery products may be ideal formations for the applications of flaxseed oil due to huge consumption of bakery products. Rangrej et al. (2015) prepared cookies incorporated flaxseed oil with different replacement ratio, and showed that the physical properties of cookies such as weight, diameter, thickness, spread ratio and breaking strength etc., improved as the replacement ratio increased. The acceptable quality of cookies was affected if shortening replacement with flaxseed oil was more than $30 \%$.

\section{Milk and milk products}

Milk and milk products are good candidates for flaxseed oil fortification due to their high consumption frequency and low storage temperature $\left(4^{\circ} \mathrm{C}\right)$ (Bermudez-Agurirre and Barbosa-Canova, 2011). Bermudez-Agurirre and Barbosa-Canova (2011) incorporated flaxseed oil into selected cheeses (queso frsco, cheddar and mozzarella), and found the obtained cheese exhibited a good storage stability, which could storage around 16 days under refrigerated conditions. Goyal et al. (2016) fortified indian yoghurt dahi by the incorporation of flaxseed oil powder, and showed that acidity of dahi fortified by flaxseed oil was higher compared to that of the control after 12 days of storage. Around 21\% ALA in fortified dahi was reduced after being stored for 15 days. Also, Veena et al. (2017) fortified dahi by using flaxseed oil, phytoserols and polydextrose. The results showed that $\mathrm{pH}$ and acidity of dahi were not influenced by the incorporation of functional compounds. What's more, fortified dahi and control samples presented similar mouthfeel. Fortified dahi contained $282.53 \mathrm{mg}$ ALA, $415.92 \mathrm{mg}$ phytoserols and $1.019 \mathrm{~g}$ polydextrose. Fortified dahi also presented highly chemical stability after 8 days of storage. Baba et al. (2018) fortified yogurt with flaxseed and walnut oils using guar gum as a stabilizer. The authors found syneresis and antioxidant properties of fortified yogurt improved, whereas the viable count in yogurt reduced, compared to the control yogurt. The sensory evaluation results indicated overall quality of yogurt fortified by walnut oil was better compared to that fortified by flaxseed oil. Kumar et al. (2017b) prepared fruit yogurt by incorporating flaxseed oil, flaxseed flour and fruits, and showed that the addition amounts of flaxseed could significantly affect sensory property of yogurt. The maximum addition of flaxseed oil into yogurt was $2.0 \%$. ALA content in optimized fruit yogurt samples could be reached up to $22.80 \%$.

\section{Meat products}

Bolger et al. (2018) showed the addition of flaxseed oil into chicken sausages affected the physical properties of the sausage matrix depended on the addition type of flaxseed oil. Encapsulated flaxseed oil form could induce greater significant influence on the physical properties of the sausage than other types of flaxseed oil. Reddy et al. (2016) investigated the possibility of rice bran oil and flaxseed oil in the development of designer chicken shred. The results showed that obtained chicken shred was with a good overall acceptability. Therefore, the authors suggested that flaxseed oil and rice bran oil can be utilized to produce healthy chicken foods. Bilska et al. (2018) fortified liver pate using flaxseed oil and flaxseed extract, and indicated the level of the saturated and monoenoic fatty acid was significantly reduced by $12 \%$ after the replacement of animal fat with flaxseed oil. What's more, the replacement also could increase phytosterols contents in liver pate. Debusca et al. (2013) fortified Alaska pollock surimi seafood by incorporating $10 \% \omega-3$ blending oil (flaxseed: algae: menhaden, 8: 1:1). The results showed that the rheological and textural properties of obtained surimi were significantly improved after the incorporation of $\omega-3$ blending oils. In the study of Pietrowski et al. (2011, 2012), impact of the addition of $\omega-3$ blending oils (flaxseed, algae, menhaden and krill) on texture property of surimi seafood was studied. The results showed that texture property of surimi was not significantly influenced after being incorporated $\omega-3$ blending oils.

\section{Ice cream}

Ice cream may be an ideal food system for incorporating flaxseed oil due to its low storage temperature $\left(-18^{\circ} \mathrm{C}\right)$. Gowda et al. (2018) prepared ice cream incorporated with flaxseed oil powder, and revealed that ALA content in fortified ice cream deceased $18.74-21.38 \%$ after 120 days of storage. The author concluded that flaxseed oil powder could be incorporated into ice cream at $4.0 \%$ level.

\section{Conclusion}

Among the bioactives in flaxseed, research scientists and consumers are interested in flaxseed oil, particularly ALA in flaxseed oil. At present, flaxseed oil-based products have been available. Though we've made some achievements, more investigations should be carried out in the future. Firstly, many consumers do not sufficiently realize the potential advantages of flaxseed oil for our health. Therefore, we need to improve cognitive ability for flaxseed oil in the future. Secondly, the high value-added flaxseed oil based products are still limited, and should 
be developed. Thirdly, because of poor stability of ALA in flaxseed oil, application of flaxseed oil in food industry still is facing a great challenge. In order to minimize oil oxidation, many advanced techniques, for example the production technology of nano-emulsion (micro-fluidization, microwave, high power ultrasound etc.), spray drying, etc., should be attempted to protect flaxseed oil, and will further expand the utilization of flaxseed oil. In addition, although more evidence have indicated flaxseed oil has health promoting benefits, many more studies need to be carried out to resolve the results regarding the mechanisms of flaxseed oil for disease treatment. Furthermore, the production of ALA enriched animal origin products by feeding flaxseed oil enriched diet, should be developed further.

\section{Conflict of interests}

None.

\section{Acknowledgments}

This work was supported by 2019 Employee Faculty Special Research Project of Tourism College of Zhejiang (No. 2019XJZD04), Research Foundation of Education Department of Zhejiang (No.Y201941046), the High Level Major Research Achievements Training program of Tourism College of Zhejiang (No. 2019GCC004) and the Project from Sichuan State Key Laboratory of Culinary Science (No. PRKX201917).

\section{Compliance with Ethics statements}

This is a review paper, which does not include animal or human experiments.

\section{References}

Abbasi, F., Samadi, F., Jafari, S.M., Ramezanpour, S. and Shargh, M.S., 2019. Ultrasound-assisted preparation of flaxseed oil nanoemulsions coated with alginate-whey protein for targeted delivery of omega- 3 fatty acids into the lower sections of gastrointestinal tract to enrich broiler meat. Ultrasonics-Sonochemistry 50: 208-217. https://doi.org/10.1016/j.ultsonch.2018.09.014

Afzal, U., Butt, M.S., Ashfaq, F., Bilal, A. and Suleria, H.A.R., 2020. Bioassessment of flaxseed powder and extract against hyperglycemia and hyprecholesterolemia using Sprague Dawley rats. Clinical Phytoscience 6: 5. https://doi.org/10.1186/s40816-020-0150-y

Aguirre, D.B. and Canovas, G.V.B., 2012. Fortification of queso fresco, cheddar and mozzarella cheese using selected sources of omega-3 and some nonthermal approaches. Food Chemistry 133: 787-797. https://doi.org/10.1016/j.foodchem.2012.01.093
Akrami, A., Nikaein, F., Bbajafari, S., Faghih, S. and Yarmohammadi, H., 2018. Comparison of the effects of flaxseed oil and sunflower seed oil consumption on serum glucose, lipid profile, blood pressure, and lipid peroxidation in patients with metabolic syndrome. Journal of Clinical Lipidology 12: 70-77. https://doi.org/10.1016/j.jacl.2017.11.004.

Anwar, F., Zreen, Z., Sultana, B. and Jamil, A., 2013. Enzyme-aided cold pressing of flaxseed (Linum usitatissimum L.): enhancement in yield, quality and phenolics of the oil. Grasas Aceites 64: 463-471. https://doi.org/10.3989/gya.132212

Arntfield, S.D., 2018. Proteins from oil-producing plants. In: Rada, Y.D. (ed.) Proteins in food processing. Woodhead Publications, London, UK, pp. 187-221. https://doi.org/10.1016/ B978-0-08-100722-8.00008-5

Aziza, A.E., Panda, A.K., Quezada, N. and Cherian, G., 2013. Nutrient digestibility, egg quality, and fatty acid composition of brown laying hens fed camelina or flaxseed meal. The Journal of Applied Poultry Research 22: 832-841. https://doi.org/10.3382/ japr.2013-00735

Baba, W.N., Jan, K., Punoo, H.A., Wani, T.A., Dar, M.M. and Masoodi, F.A., 2018. Techno-functional properties of yoghurts fortified with walnut and flaxseed oil emulsions in guar gum. LWT-Food Science and Technology 92: 242-249. https://doi. org/10.1016/j.lwt.2018.02.007

Bakowska-Barczak, A., Larminat, M.A. and Kolodziejczyk, P.P., 2020. The application of flax and hempseed in food, nutraceutical and personal care products. In: Kozlowski, R.M. and Talzarczyk, M.M. (eds.) Handbook of natural fibres. Woodhead Publishing, London, UK, pp. 557-590. https://doi.org/10.1016/ B978-0-12-818782-1.00017-1

Bechlin, T.R., Granella, S.J., Christ, D., Coelho, S.R.M. and Viecelli, C.A., 2019. Evaluation of grain and oil quality of packaged and ozonized flaxseed. Journal of Stored Products Research 83: 311-316. https://doi.org/10.1016/j.jspr.2019.07.014

Bekhit, A.A., Shavandi, A., Jodjaja, T., Birch, J., Tech, S., Ahmed, I.S.A., et al. 2018. Flaxseed: composition, deoxification, utilization, and opportunities. Biocatalysis \& Agricultural Biotechnology 13: 129-152. https://doi.org/10.1016/j.bcab.2017. 11.017

Bermudez-Aguirre, D. and Barbosa-Canovas, G.V., 2011. Quality of selected cheeses fortified with vegetable and animal sources of omega-3. LWT-Food Science and Technology 44: 1577-1584. https://doi.org/10.1016/j.lwt.2011.01.023

Bilska, A., Waszkowiak, K., Blaszyk, M., Rudzinska, M. and Kowalski, R., 2018. Effect of liver pate enrichment with flaxseed oil and flaxseed extract on lipid composition and stability. Journal of the Science and Food Agriculture 98: 4112-4120. https://doi.org/10.1002/jsfa.8928

Bolger, Z., Brunton, N.P. and Monahan, F.J., 2018. Impact of inclusion of flaxseed oil (pre-emulsified or encapsulated) on the physical characteristics of chicken sausages. Journal of Food Engineering 230: 39-48. https://doi.org/10.1016/j.jfoodeng.2018.02.026

Buckner, A.L., Buckner, C.A., Montaut, S. and Lafrenie, R.M., 2019. Treatment with flaxseed oil induces apoptosis in cultured malignant cells. Heliyon 5: e02251. https://doi.org/10.1016/j.heliyon. 2019.e02251 
Chen, F., Wang, W. and Yin, Y., 2019a. Heat stability of flaxseed oil. Cereals Oils 32: 25-26.

Chen, F., Wang, Y., Wang, H., Dong, Z., Wang, Y., Zhang, M.,et al. 2019b. Flaxseed oil ameliorated high-fat-diet-induced bone loss rats by promoting osteoblastic function in rat primary osteoblasts. Nutrition \& Metabolism 16: 71. https://doi.org/10.1016/j. heliyon.2019.e02251

Dabrowski, G., Czaplicki, S. and Konopka, I., 2019. Fractionation of sterols, tocols and squalene in flaxseed oils under the impact of variable conditions of supercritical $\mathrm{CO}_{2}$ extraction. Journal of Food Composition and Analysis 83: 103261. https://doi. org/10.1016/j.jfca.2019.103261

Debusca, A., Tahergorabi, R., Beamer, S.K., Partington, S. and Jaczynski, J., 2013. Interactions of dietary fibre and omega-3rich oil with protein in surimi gels developed with salt substitute. Food Chemistry 141: 201-208. https://doi.org/10.1016/j. foodchem.2013.02.111

DeLuca, J.A.A., Garcia-Villatoro, E.L. and Allred, C.D., 2018. Flaxseed bioactive compounds and colorectal cancer prevention. Current Oncology Reports 20: 59. https://doi.org/10.1007/ s11912-018-0704-z

Deng, Q., Yu, X., Ma, F., Xu, J., Huang, F., Huang, Q. et al. 2017. Comparative analysis of the in-vitro antioxidant activity and bioactive compounds of flaxseed in China according to variety and geographical origin. International Journal of Food Properties 20: S2708-S2722. https://doi.org/10.1080/10942912.2017.1402029

Dunford, N.T., 2015. Hemp and flaxseed oil: properties and applications for use in food. In: Talbot, G. (ed.) Specialty oils and fats in food and nutrition. Woodhead Publishing, London, UK, pp. 39-63.

Edel, A.L., Aliani, M. and Pierce, G.N., 2015. Stability of bioactives in flaxseed and flaxseed-fortified foods. Food Research International 77: 140-155. https://doi.org/10.1016/j.foodres. 2015.07.035

El-Beltagi, H.S., Salama, Z.A. and El-Hariri, D.M., 2011. Variations in oil and some phytochemical contents in flaxseed cultivars (Linum Usitatissimum L.). Electronic Journal of Environmental, Agricultural and Food Chemistry 10: 2711-2721.

El-Saeed, G.S.M., Elghoroury, E.A., Morsy, S., Aly, H.M. and Wafaey, H., 2018. Phenotype of vitamin D receptor gene polymorphisms, impact of feeding flaxseed oil, osteoporosis in ovariectomised diabetic rats. Bullet National Research Centre 42: 11. https://doi.org/10.1186/s42269-018-0003-8

El-Waseif, M.A., El-Dayem, H.H.A., Hashem, H.A. and El-Behairy, S.A., 2014. Hypolipidemic effect of fat spreads containing flaxseed oil. Annals of Agricultural Science 59: 17-24. https://doi.org/10.1016/j. aoas.2014.06.003

El-Waseif, M.A., Hashem, H.A. and El-Dayem, H.H.A., 2013. Using flaxseed oil to prepare therapeutical fat spreads. Annals of Agricultural Science 58: 5-11. https://doi.org/10.1016/j.aoas.2013.01.002

Eratte, D., Dowling, K., Barrow, C.J. and Adhikari, B., 2018. Recent advances in the microencapsulation omega-3 oil and probiotic bacteria through complex coacervation: a review. Trends in Food Science \& Technology 71: 121-131. https://doi.org/10.1016/j. tifs.2017.10.014

Eratte, D., McKnight, S., Gengenbach, T.R., Dowling, K., Barrow, C.J. and Adhikari, B.P., 2015. Co-encapsulation and characterisation of omega-3 fatty acids and probiotic bacteria in whey protein isolate-gum Arabic complex coacervates. Journal of Functional Foods 19: 882-892. https://doi.org/10.1016/j. jff.2015.01.037

Eratte, D., Wang, B., Dowling, K., Barrow, C.J. and Adhikari, B., 2016. Survival and fermentation activity of probiotic bacteria and oxidative stability of omega-3 oil in co-microcapsules during storage. Journal of Functional Foods 23: 485-496. https://doi. org/10.1016/j.jff.2016.03.005

FAO. Available at: http://www.fao.org/faostat/zh/\#data/QC. accessed at 14th March, 2020.

Farbod, F., Kalbasi, A., Moini, S., Emam-Djomeh, Z., Razavi, H. and Mortazavi, A., 2015. Effects of storage time on compositional, micro-structural, rheological and sensory properties of low fat Iranian UF-Feta cheese fortified with fish oil and fish oil powder. Journal of Food Science and Technology 52: 1372-1382. https:// doi.org/10.1007/s13197-013-1163-Z

Fathi-Achachlouei, B., Azadmard-Damirchi, S., Zahedi, Y. and Shaddel, R., 2019. Microwave pretreatment as a promising strategy for increment of nutraceutical content and extraction yield of oil from milk thistle seed. Industrial Crops and Products, 128: 527-533. https://doi.org/10.1016/j.indcrop.2018.11.034

Fioramonti, S.A., Stepanic, E.M., Tibaldo, A.M., Pavon, Y.L. and Santiago, L.G., 2019. Spray dried flaxseed oil powdered microcapsules obtained using milk whey proteins-alginate double layer emulsions. Food Research International 119: 931-940. https://doi.org/10.1016/j.foodres.2018.10.079

Gerstenmeryer, E., Reimer, S., Berghofer, E., Schwartz, H. and Sontag, G., 2013. Effect of thermal heating on some lignans in flax seeds, sesame seeds and rye. Food Chemistry 138: 18471855. https://doi.org/10.1016/j.foodchem.2012.11.117

Giarola, T.M.O., Pereira, C.G., Prado, M.E.T., de Abreu, L.R. and de Resende, J.V., 2019. Effect of golden flaxseed flour on ice recrystallization in Uvaia (Eugenia pyriformis Cambess.) diet sherbet. Food and Bioprocess Technology 12: 2120-2135. https://doi. org/10.1007/s11947-019-02377-w

Gokmen, V., Magol, B.A., Lumaga, R.B., Fogliano-Vincezo, F. and Kaplun, Z., 2011. Development of functional bread containing nanoencapsulated omega-3 fatty acids. Journal of Food Engineering 105: 585-591. https://doi.org/10.1016/j. jfoodeng.2011.03.021

Gowda, A., Sharma, V., Goyal, A., Singh, A.K. and Arora, S., 2018. Process optimization and oxidative stability of omega-3 ice cream fortified with flaxseed oil microcapsules. Journal of Food Science and Technology 55: 1705-1715. https://doi.org/10.1007/ s13197-018-3083-4.

Goyal, A., Patel, A., Sihag, M.K., Shah, N. and Tanwar, B., 2018. Therapeutic potential of flaxseed. In: Grumezescu, A.M. and Holban, A.M. (eds.) Theraperutic, probiotic, and unconventional foods. Academic Press, Oxford, UK, pp. 255-274. https:// doi.org/10.1016/B978-0-12-814625-5.00013-3

Goyal, A., Sharma, V., Sihag, M.K., Singh, A.K., Arora, S. and Sabikhi, L., 2016. Fortification of dahi (Indian yoghurt) with omega-3 fatty acids using microencapsulated flaxseed oil microcapsules. Journal of Food Science and Technology 53: 24222433. https://doi.org/10.1007/s13197-016-2220-1 
Hall, C., Tulbek, M.C. and Xu, Y., 2006. Flaxseed. In: Taylor, S.L. (ed.) Advance in food and nutrition research. Elsevier Press, New York, USA, pp. 1-97. https://doi.org/10.1016/ S1043-4526(06)51001-0

Han, H., Qiu, F., Zhao, H., Tang, H., Li, X. and Shi, D., 2018. Dietary flaxseed oil improved western-type diet-induced atherosclerosis in apolipoprotein-E knockout mice. Journal of Functional Foods 40: 417-425. https://doi.org/10.1016/j.jff.2017.11.031

Hashempour-Baltork, F., Torbati, M., Azadmard-Damirchi, S. and Savage, G.P., 2016. Vegetable oil blending: a review of physicochemical, nutritional and health effects. Trends in Food Science \& Technology 57: 52-58. https://doi.org/10.1016/j. tifs.2016.09.007

Hashemzadeh, A.A., Nasoohi, N., Raygan, F., Aghadavod, E., Akbari, E., Taghizadeh, M., et al. 2017. Flaxseed oil supplementation improve gene expression levels of PPAR- $\gamma, \mathrm{LP}(\mathrm{a}), \mathrm{IL}-1$ and TNF- $\alpha$ in type 2 diabetic patients with coronary heart disease. Lipids 52: 907-915. https://doi.org/10.1007/s11745-017-4295-5

Hussein, J., El-Khayat, Z., Shaker, O., El-Matty, D.A., Rasheed, W. and Raafat, J., 2014. Flaxseed oil influences incorporation of glucose transporters in erythrocyte membranes during experimental diabetes in rats. Planta Medica 80: LP74. https://doi. org/10.1055/s-0034-1395110

Ismail, A.F.M., Slaem, A.A.M. and Eassawy, M.M.T., 2016. Modulation of gamma-irradiation and carbon tetrachloride induced oxidative stress in the brain of female rats by flaxseed oil. Journal of Photochemistry \& Photobiology, B: Biology 161: 91-99. https://doi.org/10.1016/j.jphotobiol.2016.04.031

Jamilian, M., Dizaji, S.H., Bahmani, F., Taghizadeh, M., Memarzadeh, M.R., Karamali, M., et al. 2017. A randomized controlled clinical trial investigating the effects of omega-3 fatty acids and vitamin E co-supplementation on biomarkers of oxidative stress, inflammation and pregnancy outcomes in gestational diabetes. Canadian Journal of Diabetes 41: 143-149. https://doi.org/10.1016/j.jcjd.2016.09.004.

Kaithwas, G. and Majumdar, D.K., 2010. Therapeutic effect of Linum usitatissimum (flaxseed/linseed) fixed oil on acute and chromic arthritic models in albino rats. Inflammopharmacology 18: 127-136. https://doi.org/10.1007/s10787-010-0033-9

Kajla, P., Sharma, A. and Sood, D.R., 2015. Flaxseed- a potential functional food source. Journal of Food Science and Technology 52: 1857-1871. https://doi.org/10.1007/s13197-014-1293-y

Kasote, D.M., Badhe, Y.S. and Hegde, M.V., 2013. Effect of mechanical press oil extraction processing on quality of linseed oil. Industrial Crops and Products 42: 10-13. https://doi. org/10.1016/j.indcrop.2012.05.015

Kaur, M., Kaur, R. and Gill, B.S., 2017. Mineral and amino contents of different flaxseed cultivars in relation to its selected functional properties. Journal of Food Measure and Characterization 11: 500-511. https://doi.org/10.1007/s11694-016-9417-x

Kaushik, P., Dowling, K., MaKnight, S., Barrow, C.J., Wang, B. and Adhikari, B., 2016. Preparation, characterization and functional properties of flax seed protein isolate. Food Chemistry 197: 212-220. https://doi.org/10.1016/j.foodchem.2015.09.106

Khattab, R. and Zeitoun, M.A., 2013. Quality evaluation of flaxseed oil obtained by different extraction techniques. LWT-Food
Science and Technology 53: 338-345. https://doi.org/10.1016/j. lwt.2013.01.004

Kheira, H.S., EI-Sayed S.A.E.S., Elsayed, G.R. and Rizk, M.A., 2019. Dietary flaxseed oil inhibits kidney NF-kappa B activation and pro-inflammatory cytokine expression in cisplatin-treated rats. Comparative Clinical Pathology 28: 349-357. https://doi. org/10.1007/s00580-018-2871-6

Kontogianni, M.D., Vlassopoulos, A., Gatzieva, A., Farmaki, A.E., Katsiougiannis, S., Panagiotakos, D.B., et al. 2013. Flaxseed oil does not affect inflammatory markers and lipid profile compared to olive oil, in young, healthy, normal weight adults. Metabolism 62: 686-693. https://doi.org/10.1016/j.metabol.2012.11.007

Kulkarni, N.G., Kar, J.R. and Singhal, R.S., 2017. Extraction of flaxseed oil: a comparative study of three-phase partitioning and supercritical carbon dioxide using response surface methodology. Food Bioprocess Technology 10: 940-948. https://doi. org/10.1007/s11947-017-1877-4.

Kumar, M.M., Faiza, S., Dabnath, S. and Nasirullah, 2017a. Status of the bioactive phytoceuticals during deep-fat frying of snack food using nutra-coconut oil. Journal of Food Science and Technology 54: 3689-3698. https://doi.org/10.1007/s13197-017-2833-z

Kumar, S.S., Balasubramanyam, B.V., Rao, K.J., Dhas, P.H.A. and Nath, B.S., 2017b. Effect of flaxseed oil and flour on sensory, physicochemical and fatty acid profile of the fruit yoghurt. Journal of Food Science and Technology 54: 368-378. https:// doi.org/10.1007/s13197-016-2471-x

Lan, Y., Ohm, J.B., Chen, B. and Rao, J., 2020. Physicochemical properties and aroma profiles of flaxseed proteins extracted from whole flaxseed and flaxseed meal. Food Hydrocolloids 104: 105731. https://doi.org/10.1016/j.foodhyd.2020.105731

Li, R., Dai, T., Tan, Y., Fu, G., Wan, Y., Liu, C. et al. 2020. Fabrication of pea protein-tannic acid complexes: impact on formation, stability, and digestion of flaxseed oil emulsions. Food Chemistry 310: 125828. https://doi.org/10.1016/j.foodchem.2019.125828

Li, X., Li, J., Dong, S., Li, Y., Wei, L., Zhao, C., et al. 2019. Effect of germination on tocopherol, secoisolarlciresinol diglucoside, cyanogenic glycosides and antioxidant activities in flaxseed (Linum usitatissimum L.). International Journal of Food Science and Technology 54: 2346-2354. https://doi.org/10.1111/ ijfs. 14098

Lim, J.Z., Ng, N.S. and Thomas, C., 2017. Prevention and treatment of diabetic food ulcers. Journal of the Royal Society of Medicine 110: 104-109. https://doi.org/10.1177/0141076816688346

Liu, J., Shim, Y.Y., Tse, T.J., Wang, Y. and Reaney, M.J.T., 2018. Flaxseed gum a versatile natural hydrocolloid for food and nonfood applications. Trends in Food Science \& Technology 75: 146-157. https://doi.org/10.1016/j.tifs.2018.01.011

Lv, B. and Huang, C.X., 2015. Flaxseed sprouted powder and a preparation method thereof. CN 201510030685: A.

Lv, J., Ma, X. and Wang, H., 2020. Effect of microwave pretreatment on yield and storage stability of flaxseed oil. China Oils and Fats 45: $13-17$.

Manshadi, A.D., Peighambardoust, S.H., Damirchi, S.A. and Niakosari, M., 2019. Oxidative and physical stability, rheological properties and sensory charcteristics of "salad dressing" samples formulated with flaxseed oil and n-OSA starch. Journal of 
Food Measurement and Characterization 13: 26-33. https://doi. org/10.1007/s11694-018-9915-0

Marambe, H.K. and Wanadsundara, J.P.D., 2017. Protein from flaxseed (Linum usitatissimum L.). In: Nadathur, S.R., Wanasundara, J.P.D. and Scanlin, L. (eds.) Sustainable protein sources. Academics Press, Oxford, UK, pp. 133-144. https://doi. org/10.1016/B978-0-12-802778-3.00008-1

Mason, J.K., Fu, M., Chen, J. and Thompson, L.U., 2015. Flaxseed oil enhances the effectiveness of trastuzumab in reducing the growth of HER2-overexpressing human breast tumors (BT474). Journal of Nutritional Biochemistry 26: 16-23. https://doi. org/10.1016/j.jnutbio.2014.08.001

Meinhart, A.D., da Siveira, T.F.F., de Morase, M.R., Petrarca, M.H., Siva, L.H., Oliveira, W.S., Wagner, R., Bolini, H.M.A., Bruns, R.E., Filho, J.T. and Godoy, H.T., 2017. Optimization of frying oil composition rich in essential fatty acids by mixture design. LWT- Food Science and Technology 84: 795-803. https://doi.org/10.1016/j.lwt.2017.06.053

Moghadam, M.H.B., Rezaei, M., Behgar, M. and Kermanshahi, H., 2019. Effects of gamma and electron radiation on chemical composition and some phyto-chemical properties of whole flaxseed. Journal of Radioanalytical and Nuclear Chemistry 321: 10191025. https://doi.org/10.1007/s10967-019-06679-3

Mohanan, A., Nickerson, M.T. and Ghosh, S., 2018. Oxidative stability of flaxseed oil: effect of hydrophilic, hydrophobic and intermediate polarity antioxidants. Food Chemistry 266: 524-533. https://doi.org/10.1016/j.foodchem.2018.05.117

Mohseni, F. and Goli, S.A.H., 2019. Encapsulation of flaxseed oil in the tertiary conjugate of oxidized tannic acid-gelatin and flaxseed (Linum usitatissimum) mucilage. International Journal of Biological Macromolecules 140: 959-964. https://doi. org/10.1016/j.ijbiomac.2019.08.197

Morshedzadeh, N., Shahrokh, S., Aghdaei, H.A., Pourhoseingholi, M.A., Chaleshi, V., Hekmatdoost, A., et al. 2019. Effects of flaxseed and flaxseed oil supplement on serum levels of inflammatory markers, metabolic parameters and severity of disease in patients with ulcerative colitis. Complementary Therapies in Medicine 46: 36-43. https://doi.org/10.1016/j.ctim.2019.07.012

Mosavat, S.H., Masoudi, N., Hajimedhipoor, H., Meybodi, M.K.E., Niktabe, Z., Tabarrai, M., et al. 2018. Efficacy of topical Limum usitatissimum L. (flaxseed) oil in knee osteoarthritis: a double-blind, randomized, placebo-controlled clinical trial. Complementary Therapies in Clinical Practice 31: 302-307. https://doi.org/10.1016/j.ctcp.2018.03.003

Moura-Assis, A., Afonso, M.S., de Oliveira, V., Morari, J., dos Santos, G.A., Koike, M., et al. 2018. Flaxseed oil in omega-3 protects aorta against inflammation and endoplasmic reticulum stress partially mediated by GPR120 receptor in obese, diabetic and dyslipidemic mice models. Journal of Nutritional Biochemistry 53: 9-19. https://doi.org/10.1016/j.jnutbio.2017.09.015

Naqshbandi, A., Rizwan, S. and Khan, F., 2013. Dietary supplementation of flaxseed oil ameliorates the effect of cisplatin on rat kidney. Journal of Functional Foods 5: 316-326. https://doi. org/10.1016/j.jff.2012.11.002

Nascimento, R.P., Lima, A.V., Oyama, L.M., Paiotti, A.P.R., Cardili, L., Martinez, C.A.R., et al. 2020. Extra virgin olive oil and flaxseed oil have no preventive effects on DSS-induced acute ulcerative colitis. Nutrition 74: 110731. https://doi. org/10.1016/j.nut.2020.110731

Oliveira, J.P.S., Silva, F.L.F., Monte, R.J.G., Matos, W.O. and Lopes, G.S., 2017. A new approach to mineralization of flaxseed (Linum usitatissimum L.) for trace element analysis by flame atomic absorption spectrometry. Food Chemistry 224: 335-341. https://doi.org/10.1016/j.foodchem.2016.12.096

Omar, A.M.S., 2018. The potential protective influence of flaxseed oil against renal toxicity induced by thioacetamide in rats. Saudi Journal of Biological Sciences 25: 1696-1702. https://doi. org/10.1016/j.sjbs.2016.09.021

Osuna, M.B., Romero, A.M., Avallone, C.M., Judis, M.A. and Bertola, N.C., 2018. Animal fat replacement by vegetable oils for formulation of breads with flour mixes. Journal of Food Science and Technology 55: 858-867. https://doi.org/10.1007/ s13197-017-2888-x

Parikh, M., Raj, P., Austria, J.A., Yu, L., Garg, B., Netticadan, T. et al. 2019. Dietary flaxseed protects against ventricular arrhythmias and left ventricular dilation after a myocardial infarction. Journal of Nutritional Biochemistry 71: 63-71. https://doi. org/10.1016/j.jnutbio.2019.06.004

Park, J.B., Park, J.S., Hayek, M.G., Reinhart, G.A. and Chew, B.P., 2011. Dietery fish oil and flaxseed oil suppress inflammation and immunity in cats. Veterinary Immunology and Immunopathology 141: 301-306. https://doi.org/10.1016/j. vetimm.2011.02.024

Pietrowski, B.N., Taherogorabi, R. and Jaczynski, J., 2012. Dynamic rheology and thermal transitions of surimi seafood enhanced with $\omega-3$ rich oils. Food Hydrocolloids, 27: 384-389. https://doi. org/10.1016/j.foodhyd.2011.10.016

Pietrowski, B.N., Taherogorabi, R., Matak, K.E., Tou, M.J. and Jaczynski, J., 2011. Chemical properties of surimi seafood nutrified with $\omega-3$ rich oils. Food Chemistry 129: 912-919. https:// doi.org/10.1016/j.foodchem.2011.05.044

Piva, G.S., Weschendelder, T.A., Franceshchi, E., Cansian, R.L., Paroul, N. and Steffens, C., 2017. Linseed (Linum usitatissimum) oil extraction using different solvents. Food Technology and Biotechnology 56: 366-372. https://doi.org/10.17113/ ftb.56.03.18.5318

Piva, G.S., Weschendelder, T.A., Franceshchi, E., Cansian, R.L., Paroul, N. and Steffens, C., 2018. Extraction and modeling of flaxseed (Linum usitatissimum) oil using sucritical propane. Journal of Food Engineering 228: 50-56. https://doi. org/10.1016/j.jfoodeng.2018.02.012

Ramel, P.R. and Marangoni, A.G., 2017. Effect of oil viscosity on oil migration in a two-phase model system (cream-filled chocolate). LWT- Food Science and Technology 84: 740-745. https://doi. org/10.1016/j.lwt.2017.06.04.1

Purushothaman, D., Brown, W.Y., Vanselow, B.A., Quinn, K. and Wu, S.B., 2014. Flaxseed oil supplementation alters the expression of inflammatory-related genes in dogs. Genetics and Molecular Research 13: 5322-5332. https://doi.org/10.4238/2014.July.24.11

Rangrej, V., Shah, V., Patel, J. and Ganorkar, P.M., 2015. Effect of shortening replacement with flaxseed oil on physical, sensory, fatty acid and storage characteristics of cookies. Journal of Food 
Science and Technology 52: 3694-3700. https://doi.org/10.1007/ s13197-014-1430-7

Reddy, K.J., Jayathilakan, K. and Pandey, M.C., 2016. Development of designer chicken shred with response surface methodology and evaluation of its quality characteristics. Journal of Food Science and Technology 53: 471-480. https://doi.org/10.1007/ s13197-015-1995-9

Ren, G., Zhang, W., Sun, S., Duan, X. and Zhang, Z., 2015. Enhanced extraction of oil from flaxseed (Linum usitatissimum L.) using microwave pre-treatment. Journal of Oleo Science 64: 10431047. https://doi.org/10.5650/jos.ess15099

Rombaut, N., Savoire, R., Hecke, E.V. and Thomasset, B., 2017. Supercritical $\mathrm{CO}_{2}$ extraction of linseed: optimization by experimental design with regards to oil yield and composition. European Journal of Lipid Science and Technology 119: 1600078. https://doi.org/10.1002/ejlt.201600078

Shadyro, O., Sosnovskaya, A. and Edimecheva, I., 2020. Effect of biologically active substances on oxidative stability of flaxseed oil. Food Technology and Biotechnology 57: 243-252. https:// doi.org/10.1007/s13197-019-04054-4.

Sharma, M., Dadhwal, K., Gat, Y., Kumar, V., Panghal, A., Prasad, R., et al. 2019. A review on newer technqiues in extraction of oleaginous flaxseed constituents. Oilseeds \& Fats Crops and Lipids 26: 14. https://doi.org/10.1051/ocl/2019006

Shen, Y., Chen, G., Xiao, A., Xie, Y. and Liu, L., 2018. In vitro effect of flaxseed oil and $\alpha$-linolenic acid against the toxicity of lipopolysaccaride (LPS) to human umbilical vein endothelial cells. Inflammopharmacology 26: 645-654. https://doi.org/10.1007/ s10787-017-0400-X

Shim, Y.Y., Gui, B., Arnison, P.G., Wang, Y. and Reaney, M.J.T., 2015. Flaxseed (Linum usitatissimum L.) oil processing and selected products. Trends in Food Science \& Technology 43: 162-177. https://doi.org/10.1016/j.tifs.2015.03.001

Sielicka, M. and Malecka, M., 2017. Enhancement of oxidative stability of flaxseed oil through flaxseed, evening primrose and black cumin cake extracts. Journal of Food Processing and Preservation 41: e13070. https://doi.org/10.1111/jfpp.13070

Singh, K.K., Mridula, D., Rehal, J. and Barnwal, P., 2011. Flaxseeda potential source of food, feed and fiber. Critical Review in Food Science and Nutrition 51: 210-222. https://doi. org/10.1080/10408390903537241

Soleimani, A., Taghizadeh, M., Bahmani, F., Badroj, N. and Asemi, Z., 2017a. Metabolic response to omega-3 fatty acid supplementation in patients with diabetic nephropathy: a randomized, double-blind, placebo-controlled trial. Clinical Nutrition 36: 79-84. https://doi.org/10.1016/j.clnu.2015.11.003

Soleimani, Z., Hasemdokht, F., Bahmani, F., Taghizadeh, M., Memarzadeh, M.R. and Asemi, Z., 2017b. Clinical and metabolic response to flaxseed oil omega-3 fatty acids supplementation in patients with diabetic food ulcer: a randomized, double-blind, placebo-controlled trial. Journal of Diabetes and Its Complications 31: 1394-1400. https://doi.org/10.1016/j.jdiacomp.2017.06.010

Soltanian, N. and Janhorbani, M., 2018. A randomized trial of the effects of flaxseed to manage constipation, weight, glycemia and lipids in constipated patients with type 2 diabetes. Nutrition and Metabolism 15: 36. https://doi.org/10.1186/s12986-018-0273-z
Stratulat, I., Britten, M., Salmieri, S., Fustier, P., St-Gelasis, D., Champagne, C.P. et al. 2014. Enrichment of cheese with bioactive lipophilic compounds. Journal of Functional Foods 6: 48-59. https://doi.org/10.1016/j.jff.2013.11.023

Suri, K., Singh, B., Kaur, A., Yadav, M.P. and Singh, N., 2020. Influence of microwave roasting on chemical composition, oxidative stability and fatty acid composition of flaxseed (Linum usitatissimum L.) oil. Food Chemistry 326: 126974. https://doi. org/10.1016/j.foodchem.2020.126974

Szydlowska-Czerniak, A., Tymczewska, A., Momot, M. and Wlodarczyk, K., 2020. Optimization of the microwave treatment of linseed for cold-pressing linseed oil-changes in its chemical and sensory qualities. LWT-Food Science and Technology 126: 109317. https://doi.org/10.1016/j.lwt.2020.109317

Tan, Z., Yang, Z., Yi, Y., Wang, H., Zhou, W., Li, F. et al. 2016. Extraction of oil from flaxseed (Linum usitatissimum L.) using enzyme-assisted three-phase partitioning. Applied Biochemistry and Biotechnology 179: 1325-1335. https://doi.org/10.1007/ s12010-016-2068-x

Tang, Z.X., 2019a. Flaxseed fat-reducing yogurt nutrition bar and a preparation method thereof. CN 201910603833.X.

Tang, Z.X., 2019b. Flaxseed yogurt for women and a making method thereof. CN 201910814791.

Tang, Z.X. and Bian, J.Z., 2018a. Flaxseed nutritional food for lowing blood lipid and a preparation method thereof. CN 201811366312:A.

Tang, Z.X. and Bian, J.Z., 2018b. Flaxseed nutritional food for strengthening brain and a production method thereof. CN 201811367137: A.

Tang, Z.X. and Bian, J.Z., 2018c. Flaxseed protein beverage and a preparation method thereof. CN 201811252507: A.

Tang, Z.X. and Bian, J.Z., 2018d. Nourishment enriched in proteins and flaxseed oil and a preparation method thereof. CN 201811252511.7.

Tang, Z.X. and Bian, J.Z., 2018e. Pregnant woman food containing alpha-linolenic acid and a preparation method thereof. CN 201811367386:A.

Tang, Z.X., Liang, J.Y. and Bian, J.Z., 2016a. Coarse cereal biscuits containing alpha-linolenic acid and a preparation method thereof. CN 201610762274: A.

Tang, Z.X., Liang, J.Y. and Bian, J.Z., 2017. Flaxseed kernel protein beverage and a preparation method thereof. CN 201710047917: A.

Tang, Z.X., Liang, J.Y. and Bian, J.Z., 2016b. Flaxseed milk tablets and a preparation method thereof. CN 201610757720: A.

Tang, Z.X., Liang, J.Y. and Bian, J.Z., 2016c. Flaxseed soft sweets and a preparation method thereof. CN 201610755288: A.

Tang, Z.X., Liang, J.Y. and Bian, J.Z., 2016d. Nutritious coarse cereal energy bar and a making method thereof. CN 201610754178: A.

Tanska, M., Mikolajczak, N. and Konopka, I., 2018. Comparison of the effect of sinapic and ferulic acids derivatives (4-vinylsyringol vs. 4-vinylguaiacol) as antioxidants of rapeseed, flaxseed, and extra virgin olive oils. Food Chemistry 240: 679-685. https://doi. org/10.1016/j.foodchem.2017.08.007

Tavarini, S., Castagna, A., Conte, G., Foschi, L., Sanmartin, C., Incrocci, L., Ranieri, A., Serra, A. and Angelini, L.G., 2019. Evaluation of chemical composition of two linseed varieties as 
sources of health-beneficial substances. Molecules 24: 3729 . https://doi.org/10.3390/molecules24203729

Tian, C., Fan, C., Liu, X., Xu, F. and Qi, K., 2011. Brain histological changes in young mice submitted to diets with different ratios of n-6/n-3 polyunsaturated fatty acids during maternal pregnancy and lactation. Clinical Nutrition 30: 659-667. https://doi. org/10.1016/j.clnu.2011.03.002

Torri, L., Bondioli, P., Folegatt, L., Rovellini, P., Piochi, M. and Morini, G., 2019. Development of Perilla seed oil and extra virgin olive oil blends for nutritional, oxidative stability and consumer acceptance improvements. Food Chemistry 286: 584591. https://doi.org/10.1016/j.foodchem.2019.02.063

Tuncel, N.B., Uygur, A. and Yuceer, Y.K., 2017. The effects of infrared roasting on $\mathrm{HCN}$ content, chemical composition and storage stability of flaxseed and flaxseed oil. Journal of the American Oil Chemists' Society 94: 877-884. https://doi.org/10.1007/ s11746-017-2982-2

Turner, T.D., Mapiye, C., Aalhus, J.L., Beaulieu, A.D., Patience, J.F., Zijlstra, R.T. et al. 2014. Flaxseed fed pork: n-3 fatty acid enrichment and contribution to dietary recommendations. Meat Science 96: 541-547. https://doi.org/10.1016/j.meatsci.2013.08.021

Tzang, B.S., Yang, S.F., Fu, S.G., Yang, H.C., Sun, H.L. and Chen, Y.C., 2009. Effects of dietary flaxseed oil on cholesterol metablolism of hamsters. Food Chemistry 114: 1450-1455. https://doi. org/10.1016/j.foodchem.2008.11.030

Varghese, M., Abhilash, M., Alex, M., Paul, M.V.S., Prathapan, A., Raghu, K.G. et al. 2017. Attenuation of arsenic trioxide induced cardiotoxicity through flaxseed oil in experimental rats. Redox Report 22: 346-352. https://doi.org/10.1080/13510002.2017.12 89313

Veena, N., Nath, B.S., Srinivas, B. and Balasubramanyam, B.V., 2017. Quality attributes of dahi prepared from milk fortified with omega-3 fatty acids, phytoserols and polydetxrose. Journal of Food Science and Technology 54: 1765-1775. https://doi. org/10.1007/s13197-017-2596-6

Wang, H., Wang, J., Qiu, C., Ye, Y., Guo, X., Chen, G., et al. 2017. Comarision of phytochemical profiles and health benefits in fiber and oil flaxseeds (Linum usitatissimum L.). Food Chemistry 214: 227-233. https://doi.org/10.1016/j.foodchem.2016.07.075

Wang, L., Tu, Z., Wang, H., Wang, S., Wang, X., Zhu, H., et al. 2018. Flaxseed oil improves liver injury and inhibits necroptotic and inflammatory signaling pathways following lipopolysaccharide challenge in a piglet model. Journal of Functional Foods 46: 482489. https://doi.org/10.1016/j.jff.2018.05.015

Wang, M., Zhang, X.J., Yan, C., He, C., Li, P., Chen, M., et al. 2016. Preventive effect of $\alpha$-linolenic acid-rich flaxseed oil against ethanol-induced liver injury is associated with ameliorating gut-derived endotoxin-mediated inflammation in mice. Journal of Functional Foods 23: 532-541. https://doi.org/10.1016/j. jff.2016.03.012

Wei, C., Liu, W., Chen, Z., Wang, Y., Zhu, M., Li, L., et al. 2018 a. Preliminary research on formation mechanism of volatile aroma from source of Maillard in flaxseed oil. China Lipids 43: 31-36.

Wei, C., Zhou, Q., Chen, Z., Wang, Y., Li, L. and Liu, W., 2018 b. Construction of aromatic fingerprint of flaxseed oil in Xinjiang. Journal of the Chinese Cereals and Oils Association 33: 104-111.
Wiggins, A.K.A., Mason, J.K. and Thompson, L.U., 2015. Growth and gene expression differ over time in alpha-linolenic acid treated breast cancer cells. Experimental Cell Research 333: 147-154. https://doi.org/10.1016/j.yexcr.2015.02.020

Xu, J., Yang, W., Deng, Q., Huang, Q. and Huang, F., 2012. Flaxseed oil and $\alpha$-lipoic acid combination reduces atherosclerosis risk factors in rats fed a high-fat diet. Lipids in Health and Disease 11: 1-7. https://doi.org/10.1186/1476-511X-11-148

Yang, J.E., Huang, Q.D., Zheng, C. and Deng, Q.C., 2011. Quality characteristics of pressed flaxseed oils from the flaxseeds roasted on different temperatures. China Oils and Fats 36: 28-31.

Yu, G., Shi, X., Hong, M., Huang, Q. and Zhou, X., 2019a. Application of high-pressure frying of flaxseed technology in pressed flaxseed oil production. China Oils and Fats 44: 6-10.

Yu, G., Shi, X., Hong, M., Huang, Q. and Zhou, X., 2019b. Effects of frying temperature of flaxseed on quality of pressed flaxseed oil. China Oils and Fats 44: 29-33.

Yu, W., Hao, N., Wu, K., Sang, Y., Song, C. and Wang, X., 2019c. Analysis of characteristic aroma components of flaxseed oils obtained by different processing techniques by HS-SPME-GSMS-O. Food Science 40: 266-272.

Yu, X., Huang, S., Cheng, C., Huang, F., Deng, Q. and Huang, Q., 2018. Composition and antioxidant characteristics of different flaxseed cultivars. Chinese Journal of Oil Crop Sciences 40: 879-888.

Yu, X., Tang, Y., Liu, P., Xiao, L., Liu, L., Shen, R., et al. 2017. Flaxseed oil alleviates chronic HFD-induced insulin resistance through remodelling lipid homeostasis in obese adipose tissue. Journal of Agricultural and Food Chemistry 65: 9635-9646. https://doi. org/10.1021/acs.jafc.7b03325

Zanqui, A.B., de Morais, D.R., da Silva, C.M., Santos, J.M., Gome, S.T.M., Visentainer, J.V., et al. 2015. Subcritical extraction of flaxseed oil with n-propane: composition and purity. Food Chemistry 188: 452-458. https://doi.org/10.1016/j. foodchem.2015.05.033

Zhang, W., Peng, H., Sun, H., Hua, X., Zhao, W. and Yang, R., 2020. Effect of acidic moisture-conditions as pretreatment for aqueous extraction of flaxseed oil with lower water consumption. Food and Bioproducts Process 121: 20-28. https://doi.org/10.1016/j. fbp.2020.01.017

Zhang, X., Wang, H., Yin, P., Fan, H., Sun, L. and Liu, Y., 2017a. Flaxseed oil ameliorates alcoholic liver disease via anti-inflammation and modulating gut microbiota in mice. Health and Disease 16: 44. https://doi.org/10.1186/s12944-017-0431-8

Zhang, X., Yin, P., Yang, L., Fan, H., Sun, L. and Liu, Y., 2017b. Oil contents in flaxseeds from different origins and fatty acid compositions of flaxseed oils. China Oils and Fats 42: 142-146.

Zhang, Z.S., Wang, L.J., Li, D., Chen, X.D. and Mao, Z.H., 2008. Ultrasound-assisted extraction of oil from flaxseed. Separation and Purification Technology 62: 192-198. https://doi. org/10.1016/j.seppur.2008.01.014

Zhao, M., Bergaentzle, M., Flieller, A. and Marchioni, E., 2019. Development and validation of an ultra-high performance liquid chromatography-high resolution mass spectrometry method for simultaneous quantification of cyanogenic glycosides and secoisolariciresinol diglucoside in flaxseed (Linum 
usitatissimum L.). Journal of Chromatography A 1601: 214-223. https://doi.org/10.1016/j.chroma.2019.04.072

Zheng, Y.L., Wiesenborn, D.P., Tostenson, K. and Kangas, N., 2005. Energy analysis in the screw pressing of whole and dehulled flaxseed. Journal of Food Engineering 66: 193-202. https://doi. org/10.1016/j.jfoodeng.2004.03.005

Zhou, Q., Ma, L., Zhao, W., Zhao, W., Han, X., Niu, J., et al. 2020. Flaxseed oil alleviates dextran sulphate sodium-induced ulcerative colitis in rats. Journal of Functional Foods 64: 103602. https://doi.org/10.1016/j.jff.2019.103602

Zhou, Y., Huang, J., Jin, Q. and Wang, X., 2018. Comparison of lipid composition of cold-pressed flaxseed oil from different origins. China Lipids 43: 125-128.
Zhu, L., Sha, L., Li, K., Wang, Z., Wang, T., Li, Y., et al. 2020. Dietary flaxseed oil rich in omega-3 suppresses severity of type 2 diabetes mellitus via anti-inflammation and modulating gut microbiota in rats. Lipids in Health and Disease 19: 20. https://doi. org/10.1186/s12944-019-1167-4

Zou, X., Chen, X., Hu, J., Wang, Y., Gong, D., Zhu, X., et al. 2017. Comparisons of proximate compositions, fatty acids profile and micronutrients between fiber and oil flaxseeds (Linum usitatissimum L.). Journal of Food Composition and Analysis 62: 168176. https://doi.org/10.1016/j.jfca.2017.06.001 